\title{
IV. The unit-stere theory: The demonstration of a natural relation between the volumes of the atoms in compounds under corresponding conditions and that of combined hydrogen
}

\section{Gervaise Le Bas B.Sc.}

To cite this article: Gervaise Le Bas B.Sc. (1908) IV. The unit-stere theory: The demonstration of a natural relation between the volumes of the atoms in compounds under corresponding conditions and that of combined hydrogen , Philosophical Magazine Series 6, 16:91, 60-92, DOI: $10.1080 / 14786440708636490$

To link to this article: http://dx.doi.org/10.1080/14786440708636490

\section{曲 Published online: 21 Apr 2009.}

Submit your article to this journal ए

\section{щll Article views: 2}

Q View related articles ¿

Citing articles: 1 View citing articles $ऍ$ 
IV. The Unit-Stere Theory: The Demonstration of a Natural Relation between the Volumes of the Atoms in Compounds under Corresponding Conditions and that of Combined Hydrogen. By Gervaise Le Bas, B.Sc.*

Palit II.

The Relative Volumes of Carbon and Hydrogen (a) in the LiqUid Olefines $\mathrm{C}_{2} \mathrm{H}_{2 n} \mid=$ and the Acetylenes $\mathrm{U}_{n} \mathrm{H}_{2 n-2}|\equiv|$, (b) in Aromatic and Hrdroaromatic Compounds.

TN a former paper (Phil. Mag. ser. 6, vol. xiv. No. 81, 1 pp. 324-350) the normal paraffin hydrocarbons $\mathrm{C}_{n} \mathrm{H}_{2 n+2}$ were dealt with. The apparent volume of a particular hydrocarbon under all physical conditions, from the melting to the critical point, was considered to be measured by the product of a number $W$, which represents the number of valencies, and a variable $\mathbf{S}$, called the unit-stere, the magnitude of which depends upon the physical circumstances of the experiment. The unit-stere $\dot{S}$ is equal to the apparent volume of hydrogen in the combined state; the apparent atomic volume of carbon being equal to $4 \mathrm{~S}$. The relation $\mathrm{C}=4 \mathrm{~S}$ thus connects the apparent volumes of the atoms in the individual hydrocarbons under the circumstances already mentioned, and as a result the equation

$$
\text { Mol. vol. of } \mathrm{C}_{n} \mathrm{H}_{2 n+2}=(6 n+2) \mathrm{S}=\mathrm{WS}
$$

is always true, at least approximately.

It is obvious that no direct comparison of the apparent volumes of the atoms in each compound is possible, but the validity of the above equation can be demonstrated from a consideration of the volumes of successive members of the paraffin series under coincident conditions. The relation is however, not always quite strictly followed in such a series, and this constitutes the first limitation of the principle of strict additivity to be met with. The explanation given of this is that the relative volumes of the carbon and hydrogen atoms are very closely in the ratio of $4: 1$ in a single compound, but that the apparent volumes of like atoms may change very slightly from compound to compound under most physical conditions. Another way of stating this is that there is no one physical condition except perhaps absolute zero at which ALL the compounds of a series are really comparable. Thus the molecular volumes of a series of homologous hydrocarbons under corresponding conditions

$$
\text { * Communicated by Prof. W. J. Pope, F.R.S. }
$$


are approximately in arithmetical series, sometimes exactly so. If this series divided by a second, necessarily arithmetical, that of the valency numbers, the respective ratios are constant or nearly so.

Thus,

$$
\frac{\mathrm{V}_{1}}{\mathrm{~W}_{1}}=\frac{\mathrm{V}_{2}}{\mathrm{~W}_{2}}=\frac{\mathrm{V}_{3}}{\mathrm{~W}_{3}}=\ldots .=\mathrm{S},
$$

a constant, which has already been referred to.

By simple arithmetical processes it is usually possible to prove that the apparent atomic volume of $\mathrm{H}$ is equal to the volume of the unit-stere, and the volume of carbon equal to $4 \mathrm{~S}$. This method is important, because it is the most direct method of proving the relation

$$
\mathrm{C}=4 \mathrm{H}=4 \frac{\mathrm{V}}{\mathrm{W}^{\circ}}
$$

It is, however, sometimes not possible to obtain very exact values of small numbers by the method of differences, and it is also necessary to exclude other relations. The following method has been devised to supplement that given above.

Let it be supposed that the apparent volumes of a series of homologous compounds like the paraffin hydrocarbons under a number of physical conditions be obtained, then, assuming that the relation $\mathrm{V}=\mathrm{WS}$ is true for a single compound,

$$
\begin{aligned}
& V_{1}, V_{2}, V_{3}, \ldots \ldots=W_{1} S, W_{2} S, W_{3} S \\
& V_{1}^{\prime}, V_{2}^{\prime}, V_{3}^{\prime}, \ldots \ldots=W_{1} S^{\prime}, W_{2} S^{\prime}, W_{3} S^{\prime},
\end{aligned}
$$

If the volumes in each series be successively divided by those of the first members, then

$$
\left.\begin{array}{c}
\frac{V_{1}}{V_{1}}, \frac{V_{2}}{V_{1}}, \frac{V_{3}}{V_{1}}, \ldots . \\
\frac{V_{1}^{\prime}}{V_{1}^{\prime}}, \frac{V_{2}}{V_{1}^{\prime}}, \frac{V_{3}^{\prime}}{V_{1}^{\prime}}, \ldots \ldots \\
\ldots . \ldots .
\end{array}\right\}=1, \frac{W_{2}}{W_{1}}, \frac{W_{3}}{W_{1}}, \ldots .
$$

The ratios so obtained must be additive, that is, the differences must be equal or nearly so, and also they should be reproduced by dividing the valencies of the successive compounds by the valency of the first.

Both of these conditions are fulfilled under corresponding conditions in a surprising manner, although sometimes not quite strictly. 
Divide the volumes of the members of the successive series by the corresponding members of the first; then

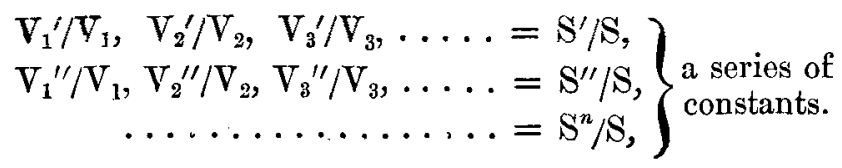

The reference points are generally the critical temperatures or pressures, but it has been found convenient to utilize the melting-points in the case of the more complex hydrocarbons.

It is no doubt a fact that the apparent molecular volumes under corresponding conditions are proportional to their real volumes, approximately at any rate. Let it be supposed that these are respectively equal to $V_{1}{ }^{0}, V_{2}{ }^{0}, V_{3}^{0}, \ldots$

Then

$$
\begin{aligned}
& \frac{V_{1}}{V_{1}{ }^{0}}, \frac{V_{2}}{V_{2}{ }^{0}}, \frac{V_{3}}{V_{3}{ }^{0}}, \ldots \ldots=\frac{\mathrm{S}}{\mathrm{S}_{0}},\left.\right|_{\text {a series of constants }}
\end{aligned}
$$

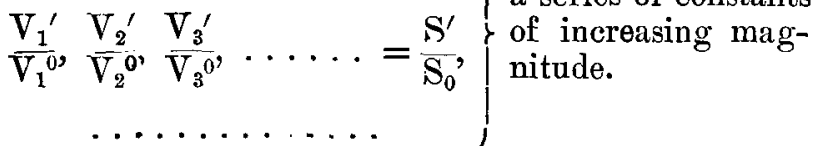

The real volumes are known to be about $\frac{1}{4}$ of the molecular critical volumes, and no doubt are equal fractions of the apparent volumes under corresponding conditions. In support of this conclusion one finds that the molecular refractions are equal fractions of the apparent volumes of the compounds under coincident conditions.

In consequence of this proportionality the molecular refractions themselves are subject to additive relations similar to those of the apparent molecular volumes of the compounds under such conditions.

\section{Unsaturated Compounds.}

\section{The Olefines and the Acetylenes.}

In view of the very interesting relations found among the saturated paraffins under corresponding conditions, the possible extension of the theory to other series is a matter of peculiar interest. Attention will be directed in this section to unsaturated hydrocarbons, (1) the olefines $\mathrm{C}_{n} \mathrm{H}_{2 n}|=|$ and the acetylenes $\mathrm{C}_{n} \mathrm{H}_{2 n-2}|\equiv|,(2)$ aromatic compounds.

In spite of the very great amount of experimental material very little of it is suitable for our present purpose, since most of the observations refer to some common temperature like $0^{\circ}$ or $20^{\circ}$. In the case of compounds belonging to the 
aliphatic series, additive volume relations will be considered at the melting-point and at the boiling-point. It is natural to suppose that some constitutive effect is noticeable, as appears to be the case when other physical properties are taken into consideration. Although there is a contraction in both the olefines and the acetylenes at the melting-point, apparently due to unsaturation, none is found when the molecular volumes of the simpler homologues of the unsaturated series are considered at the boiling-point. Very much more experimental work will have to be done before it is possible to draw any very general conclusions, and under as great a variety of physical conditions as possible. Only the barest outlines of the theory can be presented under the circumstances, and it is possible that it will have to be modified in certain of its details in the light of fuller knowledge, and with much more extended experimental material than is available at present.

(a) The Olefines, $\mathrm{C}_{n} \mathrm{H}_{2 n}|=|$. (Krafft, Ber.1886, xvi. p. 3018.)

\section{TABLe $I$.}

Table of Volumes of the Olefines at the M.P.

\begin{tabular}{|c|c|c|c|c|c|c|}
\hline No. & Olefine, $\mathrm{C}_{n} \mathrm{H}_{2 n \cdot}=$ & W. & V. & $\Delta$. & $\frac{\text { M.P. }}{\overline{\text { B.P. }}}$ & $\begin{array}{l}\text { WS } \\
-250 .\end{array}$ \\
\hline $\begin{array}{l}1 . \\
2 . \\
3 . \\
4 .\end{array}$ & $\begin{array}{l}\text { Dodecylene, } \mathrm{C}_{12} \mathrm{H}_{24}:=\mid \\
\text { Tetradecylene, } \mathrm{C}_{14} \mathrm{H}_{23}|=| \\
\text { Hexadecylene, } \mathrm{C}_{16} \mathrm{H}_{32} !=\mid\end{array}$ & $\begin{array}{r}72 \\
84 \\
96 \\
108\end{array}$ & $\begin{array}{l}211 \cdot 2 \\
246 \cdot 9 \\
282 \cdot 9 \\
318 \cdot 6\end{array}$ & $\begin{array}{l}35 \cdot 7 \\
36 \cdot 0 \\
35 \cdot 7\end{array}$ & $\begin{array}{l}\cdot 656 \\
\cdot 652 \\
\cdot 647 \\
\cdot 644\end{array}$ & $\begin{array}{l}211 \div \\
247 \cdot 03 \\
2827 \\
318 \cdot 3\end{array}$ \\
\hline \multicolumn{7}{|c|}{$\begin{array}{r}\text { Mean value .............. } 35.8 \\
12 \times 2.98\end{array}$} \\
\hline
\end{tabular}

The value of $S$ used in the calculation of the molecular volume is $2 \cdot 970$ - a number which is justified by the very close approximation of the calculated to the observed values.

The contraction for unsaturation is 2.50 at the meltingpoint in the above cases.

In order to obtain a more extended view, it is, however, necessary to study the liquid volumes of the olefines above the melting-point. For this reason, calculations similar to those followed for the saturated paraffin series are here worked out. 
TABLE II.

Table of Constants.

\begin{tabular}{|c|c|c|c|c|c|c|}
\hline Olefine, $\mathrm{C}_{n} \mathrm{H}_{2 n} \mid=$. & W. & M.W. & (ubs.) & $d_{\mathbf{s}^{\prime}}$ & a. & $\beta$. \\
\hline Dodecylene, $\quad \mathrm{C}_{12} \mathrm{H}_{24}|=| \ldots$ & 72 & 168 & $242^{\circ}$ & $\cdot 7954$ & -0008997 & -.00000022 \\
\hline Tetradecylene, $\mathrm{C}_{14} \mathrm{H}_{28} i=1 \ldots$ & 84 & 196 & $261^{\circ}$ & 7936 & -0008869 & -.00000017 \\
\hline Hexadecylene, $\mathrm{C}_{16} \mathrm{H}_{32}|=| \ldots$ & 96 & 224 & $277^{\circ}$ & 7917 & -0008556 & -00000040 \\
\hline Octadecylene, $\mathrm{C}_{1.8} \mathrm{H}_{36}|=| \quad .$. & 108 & 252 & $291^{\circ}$ & $\cdot 7910$ & -000872 & $\ldots$ \\
\hline
\end{tabular}

The method which is adopted for calculating the amount of the contraction is expressed by the following formula :-

$$
\begin{aligned}
& \text { M.V. of } \mathrm{C}_{n} \mathrm{H}_{2 n+2}-\mathrm{M} . \mathrm{V} \text {. of } \mathrm{C}_{n} \mathrm{H}_{2 n} l=l=\Delta \text { for } \mathrm{H}_{2}+l=l \text {, } \\
& l=l=-\Delta+\text { Vol. of } \mathrm{H}_{2} \text {. }
\end{aligned}
$$

The apparent volume of $\mathrm{H}$ at corresponding temperatures, that is, those which are equidistant from the respective melting-points, are given in the tables of results for the normal paraffins. Column 4 gives $\mathrm{V}$ the molecular volumes of the olefines at the different temperatures, and column 5 the volumes $V^{\prime}$ for the corresponding normal paraffins.

\section{TABLE III.}

Dodecylene, $\mathrm{C}_{12} \mathrm{H}_{24}|=|$. M.W. 168. W. 72. M.P. $-31^{\circ}$. $d_{\mathrm{T}}=\cdot 7954\left\{1-\cdot 0008997 t-00000022 t^{2}\right\}$.

$$
\begin{array}{ccc}
t & \text { Calc. sp. gr. } & \text { Observed sp. gr. } \\
-31^{\circ} \ldots \ldots \ldots \ldots & \ldots \ldots . . & 7954
\end{array}
$$

\begin{tabular}{|c|c|c|c|c|c|c|c|c|}
\hline & $\mathrm{T}$ & d. & $\frac{d_{\mathrm{T}}}{d_{\mathbf{T}^{\prime}}}$ & $\nabla$. & $\mathbf{V}^{\prime}$. & $\Delta$. & $\mathrm{H}_{2}$ & $1=1$ \\
\hline $\begin{array}{l}242 \\
252 \\
262 \\
272 \\
282 \\
292 \\
302 \\
312\end{array}$ & 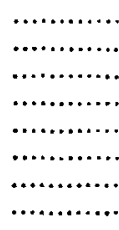 & $\begin{array}{l}.7954 \\
.7882 \\
.7810 \\
.7739 \\
.7664 \\
7592 \\
.7518 \\
.7445\end{array}$ & $\begin{array}{l}1.0000 \\
0.9910 \\
0.9819 \\
0.9730 \\
0.9636 \\
0.9544 \\
0.9452 \\
0.9360\end{array}$ & $\begin{array}{l}211 \cdot 21 \\
213 \cdot 14 \\
215 \cdot 11 \\
217 \cdot 08 \\
219 \cdot 21 \\
221 \cdot 29 \\
223 \cdot 45 \\
225 \cdot 67\end{array}$ & $\begin{array}{l}219 \cdot 93 \\
221 \cdot 84 \\
223 \cdot 86 \\
225 \cdot 91 \\
228 \cdot 06 \\
230 \cdot 23 \\
232 \cdot 49 \\
234 \cdot 77\end{array}$ & $\begin{array}{l}-8.72 \\
-8.70 \\
-8.75 \\
-8.83 \\
-8.85 \\
-8.94 \\
-9.04 \\
-9.10\end{array}$ & $\begin{array}{l}5 \cdot 94 \\
6 \cdot 00 \\
6 \cdot 05 \\
6 \cdot 10 \\
6 \cdot 15 \\
6 \cdot 22 \\
6 \cdot 28 \\
6 \cdot 34\end{array}$ & $\begin{array}{l}-2 \cdot 78 \\
-2 \cdot 70 \\
-2 \cdot 70 \\
-2 \cdot 73 \\
-2 \cdot 70 \\
-2 \cdot 72 \\
-2 \cdot 76 \\
-2 \cdot 73\end{array}$ \\
\hline & & & & & \multicolumn{3}{|c|}{ Mean contraction $=$} & $2 \cdot 73$ \\
\hline
\end{tabular}$$
\pm 0 \ldots \ldots \ldots . .7731 \quad .7729
$$$$
+15 \ldots \ldots \ldots . . \quad \cdot 7621 \quad 7620
$$$$
+30 \ldots \ldots \ldots \ldots .7511 \quad 7511
$$ 
Values of $\mathrm{V} / \mathrm{W}$ in $\mathrm{C}_{12} \mathrm{H}_{24} \mid=$. $\quad$ W. 72 .

\begin{tabular}{|c|c|c|c|c|c|}
\hline$\Gamma$. & V. & $v+i=1$. & $\mathrm{V} / \mathrm{W}$. & $\begin{array}{l}\text { Vol. of } \\
\mathrm{C}_{12} \mathbf{H}_{26}\end{array}$ & $\mathrm{~V} / \mathrm{W}$ \\
\hline 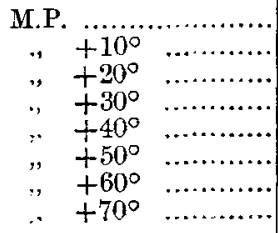 & $\begin{array}{l}211 \cdot 21 \\
213 \cdot 14 \\
215 \cdot 11 \\
217 \cdot 08 \\
219 \cdot 21 \\
221 \cdot 29 \\
223 \cdot 45 \\
225 \cdot 67\end{array}$ & $\begin{array}{l}213.94 \\
215 \cdot 87 \\
217 \cdot 84 \\
219 \cdot 81 \\
221.94 \\
224.02 \\
226 \cdot 18 \\
228 \cdot 40\end{array}$ & $\begin{array}{l}2 \cdot 971 \\
2 \cdot 998 \\
3025 \\
3 \cdot 053 \\
3 \cdot 082 \\
3 \cdot 111 \\
3 \cdot 141 \\
3 \cdot 171\end{array}$ & $\begin{array}{l}219 \cdot 93 \\
221 \cdot 84 \\
223 \cdot 86 \\
225 \cdot 91 \\
228 \cdot 04 \\
230 \cdot 23 \\
232 \cdot 49 \\
234 \cdot 77\end{array}$ & $\begin{array}{l}2 \cdot 970 \\
2 \cdot 997 \\
3 \cdot 025 \\
3 \cdot 05: 3 \\
3 \cdot 081 \\
3 \cdot 111 \\
3 \cdot 142 \\
3 \cdot 173\end{array}$ \\
\hline
\end{tabular}

Ietradecylene, $\mathrm{C}_{14} \mathrm{H}_{28}|=|$. M.W. 196. W. 84. M.P. $-12^{\circ}$.

$$
d_{\mathrm{T}}=\cdot 7936\left\{1-\cdot 0008869 t-\cdot 00000017 t^{2}\right\}
$$

t. Cale. sp. gr. Observed sp. gr.

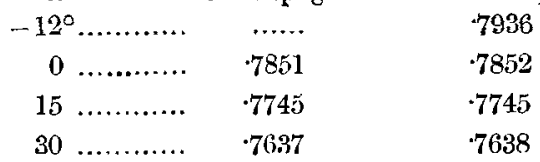

\begin{tabular}{|c|c|c|c|c|c|c|c|c|}
\hline & T. & $d_{\mathrm{T} /}$ & $\frac{d_{\mathfrak{T}}}{d_{1^{\prime}}}$ & V. & $\nabla^{\prime}$. & $\Delta$. & $\mathrm{H}_{2}$. & $1=1$ \\
\hline $\begin{array}{l}261 \\
271 \\
281 \\
291 \\
301 \\
311\end{array}$ & 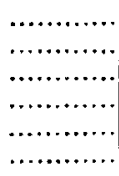 & $\begin{array}{l}7936 \\
.7865 \\
7795 \\
7723 \\
\cdot 7652 \\
.7580\end{array}$ & $\begin{array}{l}1.0000 \\
0.9911 \\
0.9822 \\
0.9732 \\
0.9642 \\
0.9552\end{array}$ & $\begin{array}{l}246 \cdot 90 \\
249 \cdot 20 \\
251 \cdot 43 \\
253 \cdot 78 \\
256 \cdot 14 \\
258 \cdot 57\end{array}$ & $\begin{array}{l}255 \cdot 40 \\
257 \cdot 68 \\
260 \cdot 03 \\
262 \cdot 45 \\
264 \cdot 88 \\
267 \cdot 34\end{array}$ & $\begin{array}{l}-8 \cdot 50 \\
-8 \cdot 48 \\
-8 \cdot 60 \\
-8 \cdot 67 \\
-8 \cdot 74 \\
-8.77\end{array}$ & $\begin{array}{l}5 \cdot 94 \\
6 \cdot 00 \\
6 \cdot 05 \\
6 \cdot 10 \\
6 \cdot 16 \\
6 \cdot 22\end{array}$ & $\begin{array}{l}-2.56 \\
-2.49 \\
-2.55 \\
-2.57 \\
-2.55 \\
-2.55\end{array}$ \\
\hline \multicolumn{8}{|c|}{ Mean contraction $\mid=1$} & $-2 \cdot 55$ \\
\hline
\end{tabular}

Values of $\mathrm{V} / \mathrm{W}$ for $\mathrm{C}_{14} \mathrm{H}_{28}=$.

\begin{tabular}{|c|c|c|c|c|c|}
\hline I. & V. & $8+1=1$ & $\mathrm{~V} / \mathrm{W}$. & $\begin{array}{l}\text { Vol. of } \\
\mathbf{C}_{24} \mathbf{H}_{30^{*}}\end{array}$ & $\mathrm{~V} / \mathrm{W}$. \\
\hline 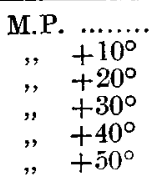 & \begin{tabular}{c|c}
$\ldots \ldots \ldots \ldots \ldots$ & 246.90 \\
$\ldots \ldots \ldots \ldots \ldots$ & $249 \cdot 20$ \\
$\ldots \ldots \ldots \ldots \ldots$ & $251 \cdot 43$ \\
$\ldots \ldots \ldots \ldots .$. & $253 \cdot 78$ \\
$\ldots \ldots \ldots \ldots .$. & $256 \cdot 14$ \\
$\ldots \ldots \ldots \ldots \ldots$ & $258 \cdot 57$
\end{tabular} & $\begin{array}{l}249 \cdot 45 \\
251 \cdot 75 \\
253 \cdot 98 \\
256 \cdot 33 \\
258 \cdot 69 \\
261 \cdot 12\end{array}$ & $\begin{array}{l}2 \cdot 970 \\
2 \cdot 997 \\
3 \cdot 023 \\
3 \cdot 051 \\
3 \cdot 080 \\
3 \cdot 109\end{array}$ & $\begin{array}{l}255 \cdot 4 \\
257 \cdot 68 \\
260 \cdot 03 \\
262 \cdot 45 \\
264 \cdot 9 \\
269 \cdot 97\end{array}$ & $\begin{array}{l}2 \cdot 970 \\
2 \cdot 996 \\
3 \cdot 023 \\
3 \cdot 051 \\
3 \cdot 080 \\
3 \cdot 108\end{array}$ \\
\hline
\end{tabular}

Phil. Mag. S. 6. Vol. 16. No. 91. July $1908 . \quad$ F 
Hexadecylene, $\mathrm{C}_{16} \mathrm{H}_{32}$. M.W. 224. W. $96 . \quad$ M.P. $4^{\circ}$. $d_{\mathrm{r}}=\cdot 7917\left\{1-\cdot 0008556 t-\cdot 000000 t^{2}\right\}$.

$t$.

$+4^{\circ}$

15

$37 \cdot 1$
Calc. sp. gr.

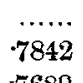

7689
Observed sp. gr.

7917

.7842

7689

\begin{tabular}{|c|c|c|c|c|c|c|c|c|}
\hline & T. & $d_{T^{\prime}}$ & $\frac{d_{\mathrm{S}}}{d_{\mathrm{T}^{\prime}}}$ & V. & $V^{\prime}$. & $\Delta$. & $\mathbf{H}_{\mathbf{2}}$ & $1=1$. \\
\hline $\begin{array}{l}277 \\
287 \\
297 \\
307\end{array}$ & $\begin{array}{l}\ldots \ldots \ldots \\
\ldots \ldots \ldots \ldots \\
\ldots \ldots \ldots \ldots \\
\ldots \ldots \ldots \ldots\end{array}$ & $\begin{array}{l}.7917 \\
.7849 \\
.7780 \\
.7710\end{array}$ & $\begin{array}{l}1 \cdot 0000 \\
0.9914 \\
0.9827 \\
0.9739\end{array}$ & $\begin{array}{l}282 \cdot 94 \\
285 \cdot 37 \\
287 \cdot 92 \\
290 \cdot 53\end{array}$ & $\begin{array}{l}291 \cdot 47 \\
294 \cdot 05 \\
296 \cdot 66 \\
299 \cdot 34\end{array}$ & $\begin{array}{l}-8 \cdot 53 \\
-8 \cdot 68 \\
-8 \cdot 74 \\
-8 \cdot 80\end{array}$ & $\begin{array}{l}5 \cdot 94 \\
6 \cdot 00 \\
6 \cdot 05 \\
6 \cdot 10\end{array}$ & $\begin{array}{l}-2 \cdot 59 \\
-2 \cdot 68 \\
-2 \cdot 69 \\
-2 \cdot 7\end{array}$ \\
\hline \multicolumn{8}{|c|}{ Mean contraction $\mid=1$} & $-2 \cdot$ \\
\hline
\end{tabular}

Values of $\mathrm{V} / \mathrm{W}$ for $\mathrm{C}_{16} \mathrm{H}_{32}$

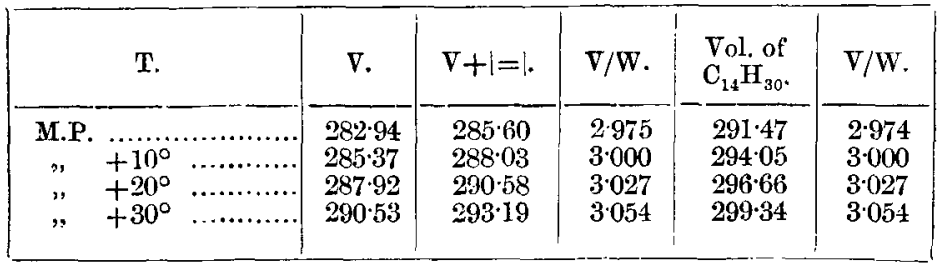

Octadecylene, $\mathrm{C}_{18} \mathrm{H}_{36}|=|$. M.W. 252. W. 108. M.P. $18^{\circ}$. $d_{\mathrm{T}}=\cdot 7910\{1-\cdot 000872 t\}$.

$t$. Calc. sp. gr. Observed sp. gr.

$\begin{array}{rrrr}+18^{\circ} & \ldots \ldots \ldots \ldots & \ldots \ldots . & 7910 \\ 22 \cdot 1 & \ldots \ldots \ldots \ldots . & .7881 & 7880 \\ 35 \cdot 6 & \ldots \ldots \ldots \ldots . & .7788 & 7790\end{array}$

\begin{tabular}{|c|c|c|c|c|c|c|c|}
\hline T. & $d_{\mathbb{T}^{\prime \prime}}$ & $\begin{array}{l}d_{\mathrm{V}^{\prime}} \\
d_{\mathrm{T}^{\prime}}\end{array}$ & V. & $V^{\prime}$. & $\Delta$. & $\mathbf{H}_{2^{2}}$ & $|=|$. \\
\hline 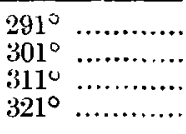 & $\begin{array}{l}7910 \\
7841 \\
.7771 \\
7702\end{array}$ & $\begin{array}{l}1 \cdot 0000 \\
0 \cdot 9913 \\
0.9825 \\
0 \cdot 9738\end{array}$ & $\begin{array}{l}318 \cdot 58 \\
321 \cdot 39 \\
324 \cdot 28 \\
327 \cdot 17\end{array}$ & $\begin{array}{l}327 \cdot 11 \\
329 \cdot 85 \\
332 \cdot 89 \\
335 \cdot 89\end{array}$ & $\begin{array}{l}-8.53 \\
-8.56 \\
-8 \cdot 61 \\
-8 \cdot 7.2\end{array}$ & $\begin{array}{l}5 \cdot 94 \\
6 \cdot 00 \\
6 \cdot 05 \\
6 \cdot 10\end{array}$ & $\begin{array}{l}-2.59 \\
-2.56 \\
-2.56 \\
-2.62\end{array}$ \\
\hline & & $\mathrm{Me}$ & of tov & \multicolumn{3}{|c|}{ Mean contraction $|=|$} & $\begin{array}{l}-2 \cdot 55 \\
-2 \cdot 62\end{array}$ \\
\hline
\end{tabular}


Values of $\mathrm{V} / \mathrm{W}$ for $\mathrm{C}_{18} \mathrm{H}_{36}|=|$.

\begin{tabular}{|c|c|c|c|c|c|c|}
\hline & T. & V. & $V+i=1$. & $\mathrm{V} / \mathrm{W}$. & $\begin{array}{l}\text { Voi, of } \\
\mathrm{C}_{18} \mathrm{H}_{38}\end{array}$ & $\nabla / N$. \\
\hline $\begin{array}{c}\text { М.P. } \\
, " \\
, \\
,,\end{array}$ & $\begin{array}{l}+10^{\circ} \\
+20^{\circ} \\
+30^{\circ}\end{array}$ & $\begin{array}{l}218 \cdot 58 \\
321 \cdot 39 \\
324 \cdot 28 \\
327 \cdot 17\end{array}$ & $\begin{array}{l}321 \cdot 13 \\
323 \cdot 94 \\
326 \cdot 83 \\
329 \cdot 72\end{array}$ & $\begin{array}{l}2 \cdot 973 \\
2 \cdot 999 \\
3 \cdot 026 \\
3053\end{array}$ & $\begin{array}{l}327 \cdot 11 \\
329 \cdot 95 \\
332 \cdot 89 \\
335 \cdot 89\end{array}$ & $\begin{array}{l}2 \cdot 973 \\
2 \cdot 999 \\
3 \cdot 026 \\
3 \cdot 053\end{array}$ \\
\hline
\end{tabular}

So far as can be seen, the contractions for unsaturation are independent both of the temperature and of the complexity of the above olefines-or at least there is no clear difference between the numbers. The contractions for unsaturation depend only upon the olefine bonds, for the apparent volumes of the atoms in the saturated portions of the molecules possess similar volumes under particular conditions to those of the normal paralins. The mean value of $|=|$ is $2 \cdot 62$.

By the simple process of adding the mean value of the contraction for each olefine to the apparent volume under each of the conditions, and then dividing by the valency number $W$, the validity of the valency rule is shown, which rule of course depends upon the fact that $\mathrm{C}=4 \mathrm{H}$ in each case. The apparent molecular volumes of the compounds are thus expressed as the sum of two terms one of which is proportional to the valency numbers $W$, and the other is constant.

M.V. of $\mathrm{C}_{n} \mathrm{H}_{2 n}:=|=6 n \mathrm{~S}-2 \cdot 62=\mathrm{WS}-|=\mid \mathrm{S}=2 \cdot 970$ at the melting-point.

\section{Table IV.}

Table showing the Values of $\mathrm{V} / \mathrm{W}$ for the Olefines at equal intervals of Temperature from the Melting-points.

\begin{tabular}{|c|c|c|c|c|c|}
\hline $\mathrm{T}$. & $\mathrm{C}_{12} \mathrm{H}_{26}$ & $\mathrm{C}_{12} \mathrm{H}_{24}|=|$. & $\left|\mathrm{C}_{14} \mathrm{H}_{28}\right|=\mid$. & $\left|\mathrm{C}_{16} \mathrm{H}_{32}\right|=$ & $\left|\mathrm{C}_{1 \gamma} \mathrm{H}_{36}\right|=!$ \\
\hline 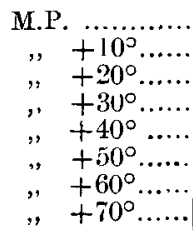 & $\begin{array}{l}2 \cdot 970 \\
2 \cdot 997 \\
3 \cdot 025 \\
3 \cdot 053 \\
3 \cdot 081 \\
3 \cdot 111 \\
3 \cdot 142 \\
3 \cdot 173\end{array}$ & $\begin{array}{l}2 \cdot 971 \\
2 \cdot 998 \\
3 \cdot 0 \cdot 25 \\
3053 \\
3 \cdot 082 \\
3 \cdot 111 \\
3 \cdot 141 \\
3 \cdot 171\end{array}$ & $\begin{array}{l}2 \cdot 970 \\
2 \cdot 997 \\
3 \cdot 023 \\
3 \cdot 051 \\
3 \cdot 080 \\
3 \cdot 109\end{array}$ & $\begin{array}{l}2.975 \\
3.000 \\
3.027 \\
3.054\end{array}$ & $\begin{array}{l}2 \cdot 973 \\
2 \cdot 999 \\
3 \cdot 026 \\
3 \cdot 053\end{array}$ \\
\hline
\end{tabular}

The above table shows in a remarkable way that the apparent volumes of the compounds above the melting-point become comparable at equal intervals of temperature therefrom, exactly as was found to be the case with the normal F 2 
paraffins. It is thus concluded:-that the relation M.V. of $\mathrm{C}_{n} \mathrm{H}_{2 n}|=|=6 n \mathrm{~S}-2 \cdot 62=\mathrm{WS}-|=|$ found to be true for the olefines at the melting-point is also true for temperatures which are at equal intervals therefrom.

It is possible to show by a method adopted for the saturated normal paraffins that under the conditions just stated additive relations hold, and also that the valency rule is alone capable of explaining the facts. In this instance dodecane $\mathrm{C}_{12} \mathrm{H}_{26}$ is taken as the standard substance, and use is made of the apparent volumes under the different circumstances, iplus the contractions $|=|$.

\section{TABLE V.}

Table showing the validity of the Valency Rule for the Olefines.

\begin{tabular}{|c|c|c|c|c|c|}
\hline $\mathrm{T}$. & $\mathrm{C}_{12} \mathrm{H}_{26}$. & $\mathrm{C}_{12} \mathrm{H}_{2 t}+1=1$. & $\mathrm{C}_{14} \mathrm{H}_{2 s}+1=1$ & $\mathrm{C}_{10} \mathrm{H}_{32}+l=1$ & $\mathrm{C}_{18} \mathrm{H}_{36}+1=1$. \\
\hline 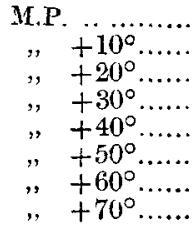 & $\begin{array}{l}1+0000 \\
" \\
" \\
" \\
" \\
" \\
"\end{array}$ & $\begin{array}{l}0.9728 \\
0.9731 \\
0.9731 \\
0.9730 \\
0.9732 \\
0.9730 \\
0.9728 \\
0.9729\end{array}$ & $\begin{array}{l}1 \cdot 1342 \\
1 \cdot 1349 \\
1 \cdot 13 \curvearrowleft 0 \\
1 \cdot 1346 \\
1 \cdot 1344 \\
1 \cdot 1342\end{array}$ & $\begin{array}{l}1.2986 \\
1.2983 \\
1.2980 \\
1.2978\end{array}$ & $\begin{array}{l}1 \cdot 4601 \\
1 \cdot 4602 \\
1.4599 \\
1.4505\end{array}$ \\
\hline Mean values .. & 1.0000 & 09730 & 11345 & $1 \cdot 2981$ & 1.4599 \\
\hline $\left.\begin{array}{l}\text { Theoretical } \\
(4: 1 \text { rule }) . . .\end{array}\right\}$ & $\frac{74}{74}$ & $\frac{72}{74}$ & $\frac{84}{74}$ & $\frac{96}{74}$ & $\frac{108}{7 \overline{4}}$ \\
\hline & $1 \cdot 0000$ & 0.9730 & $1 \cdot 1351$ & $1 \cdot 2973$ & $1 \cdot 4595$ \\
\hline Errors........ & $\cdots \ldots$ & \pm 0 & +0.0006 & -0.0008 & -0.0004 \\
\hline
\end{tabular}

The above table shows in a striking way that the relations attaching to the apparent molecular volumes of the olefines under the above cireumstances are additive, for the differences between the mean values of the ratios are nearly equal to $\cdot 1620$.

Also, the validity of the valency rule, under the different conditions, is evident from the fact, that the mean values of the ratios follow very closely those obtained by dividing the valency numbers of the various olefines by the valency number of dodecane $\mathrm{C}_{12} \mathrm{H}_{26}$. 
The remarkable consistency of the numbers representing the ratios suggests the possibility of obtaining approximate values of $\mathrm{V} / \mathrm{W}$; and thus of the apparent volumes of hydrogen, without taking the contractions into consideration. This is done by finding by difference the apparent volumes of the homologous increment $\mathrm{CH}_{2}$ and then dividing by 6 . The following table shows the closeness of the correspondence between the values of $\mathrm{V} / \mathrm{W}$ obtained in this way and those derived by taking the contractions into account.

TABLE VI.

Volumes of $\mathrm{V} / \mathrm{W}$ for the Olefines by differences.

\begin{tabular}{|c|c|c|c|c|c|c|}
\hline${ }^{\mathrm{T}} \mathrm{P}$ & $\mid \begin{array}{c}\text { Vol. of } \\
\mathrm{C}_{14} \mathrm{H}_{23} l=l\end{array}$ & $\begin{array}{c}\text { Vol. of } \\
\mathrm{C}_{12} \mathrm{H}_{24} \mid=1 .\end{array}$ & $\Delta$ for $2 \mathrm{CH}_{2}$ & $\frac{\Delta}{12}$ & $\begin{array}{l}\text { V/W from } \\
\mathrm{C}_{12} \mathrm{H}_{26}\end{array}$ & Diff. \\
\hline $\begin{array}{r}\text { M.P. } \ldots \ldots \\
\Rightarrow+10^{\circ} \ldots \\
\Rightarrow+20^{\circ} \ldots \\
",+30^{\circ} \ldots \\
" \quad+40^{\circ} \ldots \\
\Rightarrow \quad+50^{\circ} \ldots\end{array}$ & $\begin{array}{l}246 \cdot 90 \\
249 \cdot 20 \\
251 \cdot 43 \\
253 \cdot 78 \\
256 \cdot 14 \\
258 \cdot 57\end{array}$ & $\begin{array}{l}211 \cdot 21 \\
213 \cdot 14 \\
215 \cdot 11 \\
217 \cdot 08 \\
219 \cdot 21 \\
221 \cdot 29\end{array}$ & $\begin{array}{l}35 \cdot 69 \\
36 \cdot 06 \\
36 \cdot 32 \\
36 \cdot 70 \\
36 \cdot 93 \\
37 \cdot 28\end{array}$ & $\begin{array}{l}2 \cdot 975 \\
3 \cdot 005 \\
3 \cdot 027 \\
3 \cdot 058 \\
3 \cdot 078 \\
3 \cdot 106\end{array}$ & $\begin{array}{l}2 \cdot 970 \\
2 \cdot 997 \\
3 \cdot 025 \\
3 \cdot 053 \\
3 \cdot 080 \\
3 \cdot 109\end{array}$ & $\begin{array}{l}+0.005 \\
+0.008 \\
+0.002 \\
+0.005 \\
-0.002 \\
-0.003\end{array}$ \\
\hline \multicolumn{6}{|c|}{ Mean difference ... } & +0.002 \\
\hline
\end{tabular}

The differences only affect the third decimal place and the mean error is quite small, and this in spite of the unavoidable discrepancies introduced by this method of calculation. The apparent volumes of carbon and hydrogen are thus similar in the paraftin and the olefin series at the melting-point and at equal intervals of temperature therefrom.

It has been shown that the specific gravities of the normal paraffins at equal intervals of temperature from the respective melting-points are equal to fractions of-their specific gravities at those points. It is remarkable that similar relations are true for the olefins, and since these substances are not believed to be associated, the probability that the 4:1 rule is a natural relation is greatly increased.

The results that have been obtained by a study of the saturated normal paraffins and of the olefins are placed side by side in the following table ( $p .70$ ) for purposes of comparison. 


\section{TABLE VII.}

Comparison between the Values of $\frac{d_{\mathrm{T}}}{d_{\mathrm{T}^{\prime}}}$ for the Paraffins and the Olefines under similar circumstances.

\begin{tabular}{|c|c|c|c|c|c|c|c|c|}
\hline T. & $\mathrm{C}_{12} \mathrm{H}_{26}$ & $\left|\mathrm{C}_{12} \mathrm{H}_{21}\right|=\mid$ & $\left|\mathbf{C}_{14} \mathbf{H}_{30}\right|$ & $\left|\mathrm{O}_{14} \mathrm{H}_{28}\right|=\mid$ & $\mathrm{C}_{\mathrm{i} 6} \mathrm{H}_{34}$ & $\mathrm{C}_{36} \mathrm{H}_{32}:=$ & $\mid \mathrm{C}_{18} \mathrm{H}_{38}$ & $\mathbf{C}_{1 s} \mathbf{H}_{36}|=|$ \\
\hline M.P. ....... & 1.0000 & 1.0000 & 1.0000 & $1 \cdot 0000$ & 1.0000 & $1 \cdot 0000$ & $1 \cdot 0000$ & 10000 \\
\hline$" \quad+10^{\circ}$ & 0.9913 & 0.9910 & 0.9911 & 0.9911 & 0.9913 & 0.9914 & 0.9913 & 09913 \\
\hline,$\quad+20^{\circ}$ & 0.9824 & 0.9819 & 0.9822 & 0.9822 & 09826 & 0.9827 & 0.9826 & 0.9826 \\
\hline$" \quad+30^{\circ}$ & 09735 & 0.9730 & 0.9732 & 0.9732 & 09738 & 0.9739 & 0.9738 & 0.9738 \\
\hline,$\quad+40^{\circ}$ & 0.9644 & 0.9636 & 0.9642 & 0.9642 & & & & \\
\hline$" \quad+50^{\circ}$ & 0.9552 & 0.9544 & 0.9556 & 0.95556 & & & & \\
\hline$\Rightarrow+60^{\circ}$ & 0.9459 & 0.9452 & & & & & & \\
\hline$"+70^{\circ}$ & 0.9368 & 0.9360 & & & & & & \\
\hline
\end{tabular}

The conclusion is that:

the specific gravities of the olefines $\mathrm{C}_{n} \mathrm{H}_{2 n}|=|$ at equal intervals of temperature from the melting-points are equal fractions of their specific gravities at those points.

(b) The Acetylene Hydrocarbons, $\mathrm{C}_{n} \mathrm{H}_{2 n-2}: \equiv 1$.

The data for the acetylenes are those of Krafft (Ber. 1887, xvii. p. 1371), and are for the liquid state at the melting-point.

\section{TABLE VIII.}

The Volume relations of the Acetylenes at the M.P.

\begin{tabular}{|c|c|c|c|c|c|c|c|}
\hline No. & Acetylene, $\mathrm{C}_{n} \mathrm{H}_{2 n-2} \mid=1$. & W. & $V$ (obs.). & $\Delta$. & Ws. & $W S-3$. & $\frac{W \cdot-1}{\bar{V}}$ \\
\hline 1. & Dodecylidene, $\quad \mathrm{C}_{12} \mathrm{H}_{22}|\ldots| \ldots$ & 70 & 2050 & & $207 \cdot 9$ & $204: 9$ & 2.971 \\
\hline 2. & Tetradecylidene, $\mathrm{C}_{14} \mathrm{H}_{26}|\equiv| \ldots$ & $8 \cdot 2$ & $240 \cdot 5$ & & 243.54 & 24054 & 2.970 \\
\hline 3. & Hexadecylidene, $\mathrm{C}_{10} \mathrm{H}_{32}|=| \ldots$ & 94 & $276 \cdot 1$ & & $279 \cdot 18$ & 27618 & 2.970 \\
\hline 4. & Octadecylidene, $\quad \mathrm{O}_{1 \times} \mathrm{H}_{36}|=| \ldots$ & 106 & $314 \cdot 82$ & & $314 \cdot 82$ & $311 \cdot 82$ & 2970 \\
\hline & Mean values... & $\ldots$ & $\ldots \ldots \ldots$ & $35 \cdot 6$ & & & \\
\hline
\end{tabular}

The calculated molecular volumes are seen to be in excellent agreement with the observed values, and the ratio 
$\frac{\mathrm{V}}{\mathrm{W}-1}$ is equal to the mean value of the unit-stere, viz. $2 \cdot 970$.

The difference for $\mathrm{C}_{2} \mathrm{H}_{4}$ is $35 \cdot 6$, which equals $12 \times 2 \cdot 967$. It follows that the volumes for hydrogen and carbon are the same in the acetylenes at the melting-point as in the normal saturated paraffins under similar circumstances.

The contraction for unsaturation is evidently not far from 3 units per gramme molecule-a number which happens to be about equal to the apparent volume of hydrogen at the melting-point. The significance of the ratio $\frac{V}{W-1}$ is thus obvious. The contraction for the acetylenes also appears to be a little larger than that for the olefines.

Owing to the fact that data exist for the formulation of interpolation equations similar to those which have been used in the discussion of the members of the two former series, it is possible to examine the volumes of the acetylenes above the melting-point in a similar way.

The ranges of temperature over which Krafft's determinations extend are sufficiently restricted to justify the use of linear formulæ, as a comparison between the observed and the calculated specific gravities show. Interpolation formulæ have been worked out for the three acetylenes dodecylidene $\mathrm{C}_{12}^{\mathrm{y}_{2}} \mathrm{H}_{22}|\equiv|$. tetradecylidene $\mathrm{C}_{14} \mathrm{H}_{26}|\equiv|$, and hexadecylidene $\mathrm{C}_{16} \mathrm{H}_{30} \equiv$, the constants for which appear in the appended table.

\section{TABLE IX.}

Table of Constants.

\begin{tabular}{|r|ll|c|c|c|c|c|}
\hline No. & Acetylene, $\mathrm{C}_{n} \mathrm{H}_{2 n-2}|\equiv|$. & W. & M.W. & M.V. & $d_{\mathrm{T}^{\prime} .}$ & $\alpha$. \\
\hline 1. & Dodecylidene, $\quad \mathrm{C}_{12} \mathrm{H}_{22}|\equiv| \ldots$ & 70 & 166 & 264 & $\cdot 8097$ & -.00092 \\
2. & Tetradecylidene, $\mathrm{O}_{14} \mathrm{H}_{26}|\equiv| \ldots$ & 82 & 194 & $279 \cdot 5$ & $\cdot 8064$ & -.00090 \\
3. & Hexadecylidene, $\mathrm{C}_{16} \mathrm{H}_{32} \mid=1 \ldots$ & 94 & 222 & 293 & $\cdot 8039$ & -.00087 \\
\hline
\end{tabular}

As before, $\mathrm{V}$ represents the molecular volume of the acetylene, and $V^{\prime}$ that of the corresponding saturated normal paraffin under similar circumstances. 
TABLE X.

Dodecylidene, $\mathrm{C}_{12} \mathrm{H}_{22} \mid$. M.W. 166 . M.P. $264^{\circ}$. $d_{\mathrm{T}}=\cdot 8097\{1-00092 t\}$.

$t$. Calc. sp. gr. Observed sp. gr.

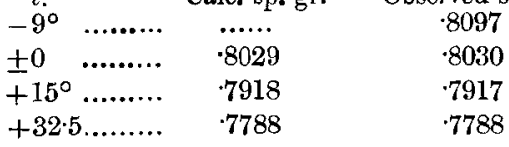

\begin{tabular}{|c|c|c|c|c|c|c|c|}
\hline T. & $d_{\mathbf{T}^{\prime}}$ & $\frac{d_{\mathrm{T}}}{d_{\mathrm{T}}}$ & V. & $\nabla^{\prime}$. & $\Delta$. & $\mathrm{H}_{4}$. & $1 \equiv 1$ \\
\hline 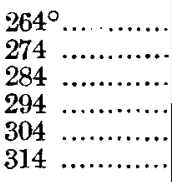 & $\begin{array}{l}.8097 \\
.8022 \\
.7948 \\
.7873 \\
.7799 \\
.7724\end{array}$ & $\begin{array}{l}1.0000 \\
0.9908 \\
0.9816 \\
0.9724 \\
09632 \\
0.9540\end{array}$ & $\begin{array}{l}205 \cdot 0 \\
206 \cdot 92 \\
208 \cdot 86 \\
210 \cdot 85 \\
212 \cdot 85 \\
214 \cdot 91\end{array}$ & $\begin{array}{l}219 \cdot 93 \\
221 \cdot 84 \\
223 \cdot 86 \\
225 \cdot 91 \\
228 \cdot 04 \\
230 \cdot 23\end{array}$ & $\begin{array}{l}-14 \cdot 93 \\
-14 \cdot 92 \\
-15 \cdot 00 \\
-15 \cdot 06 \\
-15 \cdot 19 \\
-15 \cdot 32\end{array}$ & $\begin{array}{l}11 \cdot 88 \\
11 \cdot 99 \\
12 \cdot 10 \\
12 \cdot 21 \\
12 \cdot 33 \\
12 \cdot 14\end{array}$ & $\begin{array}{l}-3 \cdot 05 \\
-2 \cdot 93 \\
-2 \cdot 90 \\
-2 \cdot 85 \\
-2 \cdot 86 \\
-2 \cdot 88\end{array}$ \\
\hline
\end{tabular}

Values of $\mathrm{V} / \mathrm{W}$ for Dodecylidene $\mathrm{C}_{12} \mathrm{H}_{22}|=|$.

\begin{tabular}{|c|c|c|c|c|c|c|}
\hline T. & & V. & $\nabla+1=1$. & $\nabla / W$ & $\begin{array}{c}\bar{\nabla} \text {. of } \\
\mathrm{C}_{12} \mathbf{H}_{26}\end{array}$ & $\mathrm{~V} / \mathrm{W}$. \\
\hline $\begin{array}{cc}\text { M.P. } & \ldots \ldots \ldots \\
, & +10^{\circ} \\
\Rightarrow & 20 \\
\Rightarrow & 30 \\
\Rightarrow & 40 \\
\Rightarrow & 50\end{array}$ & 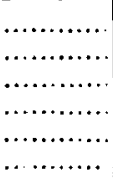 & $\begin{array}{l}205 \cdot 0 \\
206 \cdot 92 \\
208 \cdot 86 \\
210 \cdot 85 \\
212 \cdot 85 \\
214 \cdot 91\end{array}$ & $\begin{array}{l}207 \cdot 91 \\
209 \cdot 83 \\
211 \cdot 77 \\
213 \cdot 76 \\
215 \cdot 76 \\
217 \cdot 82\end{array}$ & $\begin{array}{l}2 \cdot 970 \\
2 \cdot 996 \\
3 \cdot 025 \\
3 \cdot 054 \\
3 \cdot 082 \\
3 \cdot 112\end{array}$ & $\begin{array}{l}219 \cdot 93 \\
221 \cdot 84 \\
223 \cdot 86 \\
225 \cdot 91 \\
228 \cdot 04 \\
230 \cdot 23\end{array}$ & $\begin{array}{l}2 \cdot 97: 2 \\
2 \cdot 998 \\
3 \cdot 325 \\
3 \cdot 053 \\
3 \cdot 082 \\
3 \cdot 111\end{array}$ \\
\hline
\end{tabular}

Tetradecylidene, $\mathrm{C}_{14} \mathrm{H}_{26}|\equiv|$.

$d_{\mathrm{T}}=\cdot 8064\{1-\cdot 00090 t\}$.

t. Calculated sp. gr. Olserved sp. gr.

$6.5^{\circ} \ldots \ldots . . . \quad$...... 8064

$15 \cdot 2 \ldots \ldots \ldots . . . \quad 8001 \quad 8000$

$\begin{array}{llll}30 & \ldots \ldots \ldots \ldots & 7092 & 7093\end{array}$

\begin{tabular}{|c|c|c|c|c|c|c|c|c|}
\hline$I$ & ᄃ. & $d_{\mathrm{T}}$ & $\frac{d_{\mathbf{T}}}{\bar{d}_{\mathbf{T}}}$ & $\nabla$. & $\mathbf{V}^{\prime}$. & $\Delta$. & $4 \mathbf{H}$ & $I \equiv 1$ \\
\hline $\begin{array}{l}6 \cdot 5^{\circ} \\
16 \cdot 5 \\
26 \cdot 5 \\
36^{2} \cdot 5\end{array}$ & 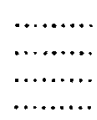 & $\begin{array}{l}.8064 \\
.7991 \\
.7918 \\
.7864\end{array}$ & $\begin{array}{l}1.0000 \\
0.9910 \\
0.9820 \\
0.9730\end{array}$ & $\begin{array}{l}240 \cdot 57 \\
942 \cdot 78 \\
244 \cdot 98 \\
247 \cdot 26\end{array}$ & $\begin{array}{l}255 \cdot 4 \\
257 \cdot 71 \\
260 \cdot 03 \\
262 \cdot 49\end{array}$ & $\begin{array}{c}-14 \cdot 83 \\
-14 \cdot 93 \\
-15 \cdot 05 \\
-15 \cdot 23\end{array}$ & $\begin{array}{l}11 \cdot 88 \\
11 \cdot 99 \\
12 \cdot 10 \\
12 \cdot 22\end{array}$ & $\begin{array}{l}-2.95 \\
-2.94 \\
-2.95 \\
-3.02\end{array}$ \\
\hline \multicolumn{8}{|c|}{ Mean contraction } & $-2 \cdot y 7$ \\
\hline
\end{tabular}


the Unit-Stere Theory.

Valnes of $\mathrm{V} / \mathrm{W}$ for Tetradecylidene $\mathrm{C}_{14} \mathrm{H}_{26} \mid=1$.

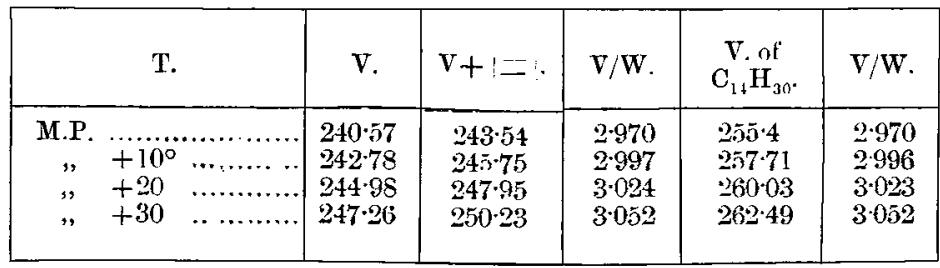

Hexadecylidene, $\mathrm{C}_{16} \mathrm{H}_{30} \mid \equiv=1$. $d_{\mathrm{T}}=\cdot 8039\{1-\cdot 00087 t\}$. t. Calc. sp. gr. Observed sp. gr.

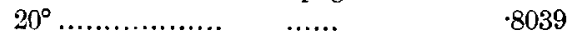

$30^{\circ} \ldots \ldots \ldots \ldots \ldots . . . . .7969 \quad 7969$

\begin{tabular}{|c|c|c|c|c|c|c|c|}
\hline$T$. & $d_{\mathbf{T}}^{\prime}$ & $\frac{d \mathrm{w}^{\prime}}{d \mathrm{r}^{\prime}}$ & V. & $v+1=1$. & $V / W$ & $\begin{array}{c}\text { V.of } \\
\mathrm{C}_{16} \mathrm{H}_{31} .\end{array}$ & $\mathrm{V} / \mathrm{W}$. \\
\hline 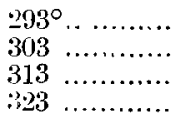 & $\begin{array}{l}.8039 \\
.7969 \\
.7899 \\
.7829\end{array}$ & $\begin{array}{l}1.0000 \\
0.9913 \\
0.9826 \\
0.9739\end{array}$ & $\begin{array}{l}276 \cdot 15 \\
278 \cdot 59 \\
281 \cdot 05 \\
283.54\end{array}$ & $\begin{array}{l}279 \cdot 15 \\
281 \cdot 59\end{array}$ & $\begin{array}{l}2.972 \\
2996 \\
3.022 \\
3.048\end{array}$ & $\begin{array}{l}291 \cdot 47 \\
294 \cdot 05 \\
296 \cdot 6 i \\
299 \cdot 34\end{array}$ & $\begin{array}{l}2 \cdot 974 \\
3 \cdot 000 \\
3 \cdot 027 \\
3 \cdot 054\end{array}$ \\
\hline
\end{tabular}

The contraction due to unsaturation is about 3 units per gramme molecule in these acetylenes, although the apparent volumes of carbon and hydrogen atoms are the same as for the normal saturated paraffins.

The general formula for the acetylenes is thus:-

$$
\text { M.V. of } \mathrm{C}_{n} \mathrm{H}_{2 n-2}|\equiv|=6 n \mathrm{~S}-2 \mathrm{~S}-3=\mathrm{WS}-1 \equiv \mid \text {. }
$$

It will now be convenient to compare the value of: $S$ for the different acetylenes, plus the amounts of the contraction, that is to say, the volumes of $\mathrm{H}$ in these compounds, with the values found for the paraffins under similar circumstances.

\section{TABLE XI.}

Table showing the validity of the Valency Rule for the Acetylenes.

\begin{tabular}{|c|c|c|c|c|c|c|}
\hline & $\mathrm{T}$. & $\mathrm{C}_{12} \mathrm{H}_{26}$ & $\left|\mathbf{C}_{12} \mathbf{H}_{22}\right| \cdots$ & $\mathrm{C}_{14} \mathrm{H}_{26}:=1$. & $\left|\mathrm{C}_{16} \mathrm{H}_{30}\right|=$ & $\mathrm{C}_{18} \mathrm{H}_{31}=$ \\
\hline $\begin{array}{c}\text { M.P. } \\
\text {," } \\
, " \\
, " \\
, "\end{array}$ & $\begin{array}{l}\ldots \ldots \ldots \\
+10^{\circ} \ldots \\
+20 \ldots \ldots \\
+30 \ldots \ldots \\
+40 \ldots \ldots \\
+50 \ldots \ldots\end{array}$ & $\begin{array}{l}2 \cdot 970 \\
2 \cdot 997 \\
3 \cdot 025 \\
3 \cdot 053 \\
3 \cdot 081 \\
3 \cdot 111\end{array}$ & $\begin{array}{l}2 \cdot 970 \\
2 \cdot 997 \\
3 \cdot 025 \\
3 \cdot 054 \\
3 \cdot 082 \\
3 \cdot 112\end{array}$ & $\begin{array}{l}2 \cdot 970 \\
2 \cdot 997 \\
3 \cdot 024 \\
3 \cdot 052\end{array}$ & $\begin{array}{l}2 \cdot 972 \\
2 \cdot 996 \\
3 \cdot 02 \cdot 3 \\
3 \cdot 048\end{array}$ & 2970 \\
\hline
\end{tabular}


The above values are significant because they represent the volumes of $\mathrm{H}$ in the acetylenes under the different circumstances.

The following alternative method, which has already been atilized, is valuable for the purpose of demonstrating the validity of the valency rule in a different way. Use is made of the observed volumes of the acetylenes at the different temperatures, plus the contractions as in the former table.

\section{TABLE XII.}

Table showing the validity of the Valency Rule for the Acetylenes.

\begin{tabular}{|c|c|c|c|c|c|}
\hline $\mathrm{T}$. & $\mathrm{C}_{12} \mathrm{H}_{26}$. & $\mathrm{C}_{12} \mathrm{H}_{22}: \equiv$ & $\mathrm{C}_{14} \mathrm{H}_{20}|=|$ & $\left|\mathrm{C}_{16} \mathrm{H}_{30}\right|=\mid$. & $\left|\mathrm{C}_{1 N} \mathrm{H}_{34}\right|=1$ \\
\hline 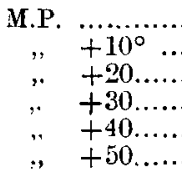 & $\begin{array}{c}1 \cdot 0000 \\
", \\
" \\
" \\
"\end{array}$ & $\begin{array}{l}0.9453 \\
0.9459 \\
0.9473 \\
0.9453 \\
09461 \\
0.9461\end{array}$ & $\begin{array}{l}1 \cdot 1073 \\
1 \cdot 1078 \\
1 \cdot 1076 \\
1 \cdot 1077\end{array}$ & $\begin{array}{l}1 \cdot 2692 \\
1 \cdot 2693 \\
1 \cdot 2688 \\
1 \cdot 2684\end{array}$ & 1.4315 \\
\hline Mean values & 1.0000 & 0.9460 & $1 \cdot 1081$ & $1 \cdot 2689$ & $1 \cdot 4315$ \\
\hline $\mathrm{W} / \mathrm{W}^{\prime}$ & $\frac{74}{74}$ & $\frac{70}{74}$ & $\frac{82}{7 \pm}$ & $\begin{array}{l}94 \\
\overline{7} \pm\end{array}$ & $\frac{106}{\overrightarrow{7} \overline{4}}$ \\
\hline & $1 \cdot 0000$ & $0 \cdot 9459$ & $1 \cdot 1081$ & 1.2702 & $1 \cdot 4324$ \\
\hline Errors & $\ldots \ldots$ & -0.0001 & +0.0005 & $+0 \cdot 0013$ & +0.0009 \\
\hline
\end{tabular}

The above table shows unmistakably that the volume relations of the acetylenes under the conditions are essentially additive, and further that the valency rule with the requisite modification for unsaturation, is alone capable of adequately expressing the results.

It is thus concluded that the general formula M.V. of $\mathrm{C}_{n} \mathrm{H}_{2 n-2}|\equiv|=6 n \mathrm{~S}-2 \mathrm{~S}-|\equiv|$ holds good not only at the melting-point but also at equal intertals of temperature therefrom.

The average contraction for unsaturation is evidently not far from 3 units for these acetylenes, and it is apparently constant, both as regards complexity and temperature, at least in the cases that have been considered.

It now remains to tabulate the results that have been obtained with reference to the values of $\frac{d_{\mathrm{T}}}{d_{\mathrm{T}}{ }^{\prime}}$. 
TABle XIII.

The validity of the Law of Coincident States.

\begin{tabular}{|c|c|c|c|c|c|c|c|c|c|}
\hline T. & $\mathrm{C}_{12} \mathrm{H}_{26}$ & $\left|\mathrm{C}_{12} \mathrm{H}_{24}\right|=$ & $\left|\mathrm{C}_{12} \mathrm{H}_{22}\right|=$ & $\mathrm{C}_{14} \mathrm{H}_{30}$ & $\mathrm{C}_{14} \mathrm{H}_{2 \downarrow}=$ & $\mathrm{C}_{11} \mathrm{H}_{21 ;}=$ & $\mathrm{C}_{1: 1} \mathrm{H}_{31}$ & $\left|\mathrm{C}_{1,5} \mathrm{H}_{3,2}\right|=$ & $\mathrm{C}_{15} \mathrm{H}_{3,1,}=$ \\
\hline M. & $1 \cdot 0000$ & 1.0000 & 1.0000 & 1.0000 & $1 \cdot 011000$ & 1.0000 & $1 \cdot \operatorname{lin}(100$ & $1 \cdot(14000$ & 1.0000 \\
\hline$+10^{\circ}$ & 0.9913 & 0.9910 & 0.9908 & 0.91010 & (6.9010 & 01910 & 0.9913 & (0.6!1) & $0 \div 113$ \\
\hline+20 & 0.9824 & 0.9819 & 09816 & $098 \div 0$ & 0.9821 & 09820 & $0.98 \div 6$ & $0 \div 18 \div 6$ & $0 \cdot 9 \cdot 20$ \\
\hline,+30 & 0.9735 & 0.9730 & 0.9724 & $10 \cdot 1730$ & 0.9731 & 0930 & 0.9738 & $13 \cdot 17.58$ & 0.138 \\
\hline$"+40$ & 0.9644 & 1).9636 & $04+332$ & & & & & & \\
\hline$" \mp$ & 0.9502 & 0.9544 & 40 & & & & & & \\
\hline
\end{tabular}

It is concluded that the following rule holds for the acetylenes as it does for the paraffins and the olefines.

The specific gracities of the acetylenes at equal intericals of temperature from the melting-points are equal fractions of their specific gravities at those points.

The law of additivity and the law of coincident states are thus considered to be true under similar circumstances for the members of the three series which have been studied, namely: the normal saturated paraffins, the olefines, and the acetylenes, and they are mutually dependent

\section{The Simpler Olefines and other Unsaturated Compounds at the Boiling-Point.}

A study of the complex saturated paraffins in the neighbourhood of the melting-point, has led to the conclusion that there is an extra contraction when two or four hydrogen atoms have been eliminated. It will be interesting to find out if this is irue when the volumes of the compounds are examined at the boiling-point.

An extended study of the data at this point shows that there is no extra contraction to be considered, that is to sily, the olefines and the acetylenes differ in volume from the saturated paraffins by an amount equal to the volumes of the hydrogen atoms by which they differ in composition. Horstmann has made a very thorough study of the differences to be observed between the volumes of saturated and olefinoid compounds at the boiling-point, and has found that the elimination of two hydrogen atoms is responsible for a contraction of abont 7.4 c.c. per gramme molecule. This number has already been shown to represent the volume of $\mathrm{H}_{2}$ under the circumstances. The evidence in favour of the relation $\mathrm{C}=4 \mathrm{H}$ is thus reasonably certain as it his been obtained under a great variety of circumstances. It is also worthy of note that the above-mentioned constant differences 
observed by Horstmann, which have long been known, now find their place in a scheme of molecular volumes.

The data referring to unsaturated compounds are far too incomplete both as regards the number and variety of substances observed and as regards the ranges of temperatures to attempt to account for the different results respecting the effect of unsaturation on molecular volumes which have been obtained at the melting- and boiling-points respectively.

The following table shows that at the boiling-point the normal paraffins and the unsaturated series of hydrocarbons fall into one scheme owing to the fact that carbon and hydrogen respectively possess approximately the same volumes in each. This is also true of hydrocarbon residues saturated and unsaturated.

\section{Table XIV.}

The Volume Relations of the Atoms in Unsaturated Compounds at the Boiling-Point.

\begin{tabular}{|c|c|c|c|c|c|}
\hline Compounds. & W. & V. & $\Delta$. & $\mathrm{V} / \mathrm{W}$. & Autbor. \\
\hline Pentane, $\mathrm{C}_{5} \mathrm{H}_{12} \ldots$ & 32 & $117 \cdot 8$ & $9 \times 3.8$ & 368 & Young. \\
\hline Anylene, $\mathrm{C}_{5} \mathrm{H}_{10} \ldots \ldots \ldots$ & 30 & $110^{\prime} 1$ & & $3 \cdot 67$ & Schiff. \\
\hline Valerylene, $\mathbf{C}_{s} \mathbf{H}_{5}$ & $\therefore 8$ & $104 \cdot 5$ & $4 \times 332$ & $3 \cdot 72$ & Buff. \\
\hline (Hexane, $\quad \mathrm{C}_{6} \mathbf{H}_{14} \ldots \ldots \ldots \ldots$ & 36 & $139 \cdot 8$ & $2 \times 370$ & $3 \cdot 68$ & Young. \\
\hline Hexylene, $\mathbf{C}_{6} \mathbf{H}_{12} \ldots \ldots \ldots$ & 34 & $132 \cdot 4$ & & $3 \cdot 68$ & Schiff. \\
\hline $\mathrm{C}_{6} \mathrm{H}_{10} \ldots \ldots \ldots$ & $3:$ & $126 \cdot 1$ & $3 \cdot 42$ & 371 & $"$ \\
\hline Heptane $\quad \mathrm{C}_{7} \mathrm{H}_{1 f} \ldots \ldots \ldots$. & 44 & $162 \cdot 56$ & $2 \times 3 \cdot 88$ & $3 \cdot 69$ & Young. \\
\hline Heptylene $\mathrm{C}_{\tau} \mathbf{H}_{1+} \ldots \ldots \ldots$ & 42 & $154 \cdot 8$ & & 3.68 & Schiff. \\
\hline Octylene, $\mathrm{C}_{5} \mathrm{H}_{1 ;} \ldots \ldots \ldots$ & 48 & $177 \cdot 6$ & & $3 \% 0$ & $"$ \\
\hline (Propyl alcohol, $\quad \mathrm{C}_{3} \mathrm{H}_{x} \mathrm{O}$ & 22 & $81 \cdot 5$ & $2 \times 3(6 j)$ & $3 \cdot 70$ & Zander. \\
\hline Allyl alcohol, $\quad \mathrm{C}_{3} \mathrm{II}_{6} \mathrm{O}$ & 20 & $74 \cdot 2$ & & 371 & " \\
\hline Propyl amine, $\quad \mathrm{C}_{3} \mathbf{I}_{9} \mathbf{N}$ & 24 & $85 \cdot 7$ & $2 \times 360$ & 357 & Schiff. \\
\hline Allyl amine, & 22 & $78 \cdot 5$ & & $35 \pi$ & $"$ \\
\hline Tripropylamine $\mathrm{N}\left(\mathrm{C}_{\sharp} \mathrm{H}_{\tau}\right)_{y}$ & 60 & $222 \cdot 4$ & $6 \times 3 \cdot 62$ & 3.70 & Zander. \\
\hline$\left\{\right.$ Triallylamine $\quad \mathbf{N}\left(\mathrm{C}_{3} \mathrm{H}_{3}\right)_{3}$ & 54 & $200 \cdot 7$ & & $3 \cdot 71$ & , \\
\hline Propyl acetate, $\quad \mathrm{C}_{5} \mathrm{H}_{10} \mathrm{O}_{2}$ & $\ldots$ & $128 \cdot 8$ & $2 \times 360$ & $\cdots$ & Schiff. \\
\hline Allyl acetate, & $\cdots$ & $121 \cdot 6$ & & $\cdots$ & , \\
\hline Propyl chloride $\mathrm{C}_{3} \mathrm{H}_{7} \mathrm{Cl}$ & .. & 917 & $2 \times 365$ & $\cdots$ & $"$ \\
\hline Allyl chloride, $\quad \mathrm{C}_{3} \mathrm{H}_{5} \mathrm{Cl}$ & $\ldots$ & $84 \cdot 4$ & & $\cdots$ & $"$ \\
\hline
\end{tabular}

It will be observed that the oxygen in the alcohols and the nitrogen in the amines possess volumes respectively equal to $2 \mathrm{~S}$ and $3 \mathrm{~S}$, thus following the law of valency. It is also 
seen that the differences for $\mathrm{H}_{2}$ in the acetates and chlorides are about the same as in the other compounds. Their volume relations are thus clearly additive. The fact that such small differences as those of $\mathrm{H}_{2}$ are fairly concordant, and that the volume of $\mathrm{H}$ is found by this means to be equal to $\mathrm{S}$, and consequently to $\mathrm{H}$ in the paraffin hydrocarbons at the boilingpoint, is sufficiently remarkable. The numbers 3.7 and $1 \pm \cdot 8$ for hydrogen and carbon respectively thus replace the numbers 5.5 and 11 in Kopp's scheme.

Diamylene $\mathrm{C}_{10} \mathrm{H}_{20}$ is a derivative of the olefine series and is formed by the polymerization of two molecules of amylene. It is not, however, supposed to belong to the olefine series, but to possess the formula

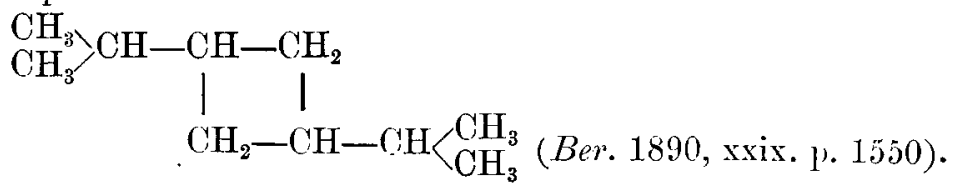

Diamylene is thus a ring compound, which fact may be expected to be indicated by its molecular volume.

$$
\begin{aligned}
& \text { M.V. of } \mathrm{C}_{10} \mathrm{H}_{20} \text { at B.P. .......... 211.7 } \\
& \begin{array}{llll}
2 \text { vols. of amylene } \mathrm{C}_{5} \mathrm{H}_{10} & \ldots \ldots \ldots . . & 220 \cdot 3
\end{array} \\
& \text { Contraction ........ } \$ .6
\end{aligned}
$$

This contraction is far too considerable to be ascribed to unsaturation, and must be attributed to the profound change in its chemical constitution indicated by its ring structure. The real contraction is, however, greater than that shown above, for the value of $\mathrm{S}$ in a compound of the complexity $\mathrm{C}_{10} \mathrm{H}_{20}$ is $3 \cdot 71\left(c p\right.$. Octane $\mathrm{C}_{8} \mathrm{H}_{10} \mathrm{~W} 50 \mathrm{~S}=3 \cdot 72$, tripropylamine $\left.\mathrm{N}\left(\mathrm{C}_{3} \mathrm{H}_{7}\right)_{3} \mathrm{~W} 60 \mathrm{~S}=3 \cdot 71\right)$. The normal volume of $\mathrm{C}_{10} \mathrm{H}_{20}$ is thus $3 \cdot 71 \times 60=222 \cdot 6$. Contraction $10 \cdot 9$. Contractions such as the above are a second departure from the principle of additivity, and are due to the effect of ring structure on molecular volumes, a matter which will be discussed more fully when aromatic and hydroaromatic compounds are considered.

The Aromatic Hydrocarbons and other Cyclic Compounds at the Boiling-Point.

(i.) A consideration of the apparent Atomic Volumes of Carbon and Hydrogen in the Side Chains at the Boiling-Point.

The compounds that are commonly called aromatic and hydroaromatic belong to a totally different class to those which have been discussed in previous papers. Whereas 
the latter are usually considered to consist of straight chains, the former are distinguished by more or less complex nuclei, the constituent atoms of which are supposed to possess it cyclic arrangement.

Before an attempt is made to work out the volume relations of the atoms in the nucleus, it will be necessary to consider the side chains, particularly those consisting of aliphatic hydrocarbon residues. It might be anticipated from their character that they should possess volumes comparable with those of equivalent residues in the hydrocarbons. This is indeed shown to be the case from the fact that the addition of the homologous increment $\mathrm{CH}_{2}$ causes an increase of 22 units at the boiling-point-a number similar to that which has been found from an examination of the molecular volumes of the paraffin hydrocarbons under similar circumstances.

The fact that the nucleus and the side chains have little reciprocal influence other than that which might be attributed to the two parts of an alipbatic hydrocarbon on each other, is strikingly shown by subtracting the volumes of the complexes $n \mathrm{CH}_{2}$ from the volumes of each benzene, and so obtaining the volume of the nucleus. In all cases the volume of the free nucleus, as found by experiment, is reproduced by making the subtraction already referred to.

The experimental study of the benzene derivatives is largely due to Schiff and also to Lossen and Zander.

\section{TABLE XV.}

The Volumes of the Nucleus and the Side Chains in Monocylic Compounds.

\begin{tabular}{|c|c|c|c|c|}
\hline \multicolumn{2}{|c|}{ Hydrocarbon. } & V. & $\Delta$. & $\begin{array}{c}\text { Calculated Volume } \\
\text { of the Nucleus. }\end{array}$ \\
\hline Benzene, & $\mathrm{C}_{6} \mathrm{H}_{6} \ldots \ldots \ldots \ldots$ & 96 & & {$[96]$} \\
\hline Toluene, & $\mathbf{C}_{7} \mathbf{H}_{8} \ldots \ldots \ldots \ldots$ & $118 \cdot 3$ & $2 \cdot 2 \cdot 3$ & $96 \cdot 1$ \\
\hline Xy'ene, & $\mathrm{C}_{8} \mathrm{H}_{10} \ldots \ldots \ldots \ldots$ & $140 \cdot 3$ & 22 & 959 \\
\hline Mesitylene, & $\mathrm{C}_{9} \mathrm{H}_{12} \ldots \ldots \ldots \ldots$ & $162 \cdot 8$ & $2+2 \cdot 5$ & $96 \cdot 2$ \\
\hline Cymene, & $\mathrm{C}_{10} \mathrm{H}_{14} \quad \ldots \ldots \ldots$ & $184 \cdot 9$ & 22.1 & $96 \cdot 1$ \\
\hline \multicolumn{2}{|c|}{ Mean $\ldots \ldots \ldots \ldots . . .}$. & $\ldots$ & 222 & $96 \cdot 07$ \\
\hline Pyridine, & $\mathrm{C}_{5} \mathrm{H}_{5} \mathrm{~N} \quad \ldots$ & $89 \cdot 3$ & 90.0 & {$[89 \cdot 3]$} \\
\hline$\beta$ Picoline. & $\mathrm{C}_{6} \mathrm{H}_{7} \mathrm{~N} \quad \ldots$ & 1115 & 22 & $89 \cdot 3$ \\
\hline Hexahydrox & lene, $\mathrm{C}_{7} \mathrm{H}_{14}$ & $141 \cdot 8$ & 0,5 & {$[141 \cdot 8]$} \\
\hline Hexahydrox & lene, $\mathrm{C}_{5} \mathrm{H}_{18} \quad \ldots$ & 164.3 & 220 & $142 \cdot 1$ \\
\hline
\end{tabular}

The conclusion to be drawn from the above figures is that the side chains occupy similar volumes to those of equivalent paraffin hydrocarbon residues, and that the volume of the 
nucleus in derivatives of this kind remains the same as that of the free nucleus. It follows that the volume of combined hydrogen is $\frac{22 \cdot 2}{6}=3.7$ and of combined carbon 14.8 as
before.

(ii.) The volumes of the six extra Hydrogen atoms in Hydroaromatic Compounds.

The six extra hydrogen atoms in hydroaromatic compounds may be viewed in the light of side chains, in which case they might be supposed to possess volumes similar to those of hydrogen atoms in the paraffin hydrocarbons under similar circumstances. It will be found that they usually do. Exceptions are found in the cases of hexamethylene and hexahydropyridine or piperidine. The extra hydrogens in these compounds appear to be more closely associated with the nucleus than is the case with hydrocarbon side chains.

\section{Table XVT.}

Table showing the Volume of $\mathrm{H}_{6}$ in Hydroaromatic Compounds. I.

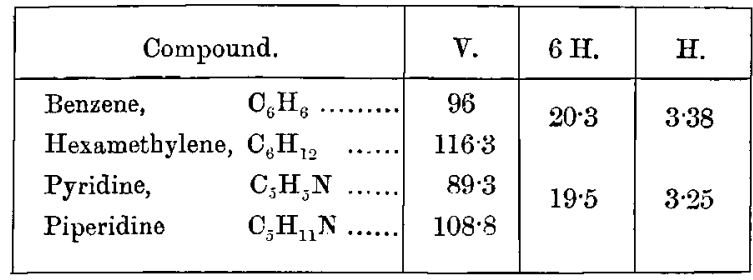

The smaller value of $\mathrm{H}$ found by difference indicates that the six extra hydrogens are closely associated with the nucleus. A more extended study of benzene and hexamethylene under corresponding conditions shows that this conclusion is correct.

This, however, ceases to hold when one or more side chains are added to the nuclei, as the following table will show.

TABLE XVII.

Table showing the Volume of $\mathrm{H}_{6}$ in Substituted Aromatic

Compounds. II.

\begin{tabular}{|lr|c|c|c|}
\hline \multicolumn{2}{|c|}{ Compound. } & V. & $6 \mathrm{H}$ & $\mathrm{H}$. \\
\hline Toluene, & $\mathrm{C}_{7} \mathrm{H}_{8} \ldots \ldots$ & $118 \cdot 3$ & $23 \cdot 8$ & $3 \cdot 97$ \\
Hydrotoluene, $\quad \mathrm{C}_{\tau} \mathrm{H}_{14} \ldots \ldots$ & $142 \cdot 1$ & & \\
Xylene, & $\mathrm{C}_{8} \mathrm{H}_{10} \ldots \ldots$ & $140 \cdot 3$ & $24 \cdot 0$ & 4.00 \\
Hexabydroxylene, & $\mathrm{C}_{8} \mathrm{H}_{16} \ldots \ldots$ & $164 \cdot 3$ & & \\
Naphthalene, & $\mathrm{C}_{10} \mathrm{H}_{8} \ldots \ldots$ & $147 \cdot 2$ & $24 \cdot 0$ & $4 \cdot 00$ \\
Naphthyl hydride, $\mathrm{C}_{10} \mathrm{H}_{14}$ & $\ldots$ & $171 \cdot 2$ & & \\
\hline
\end{tabular}


The volume of a single hydrogen in these compounds is about 4 , that is, a little higher than its volume in the paraffins. The number is, however, much higher than that found in the unsubstituted hydroaromatic compounds, and this may be attributed to the effect of the side chains or to spatial considerations. Curiously enough, the unsaturated part of the naphthalene has precisely the same effect as that of an aliphatic side chain.

It is thus concluded-

(a) That the volume of $\mathrm{CH}_{2}$ is $22 \cdot 2$ on the average in the homologues of benzene.

(b) 'The volume of the extra hydrogens in the hydroaromatic hydrocarbons varies from 3.25 to 4 at the boiling-point.

(iii.) The apparent Atomic Volumes in the Nucleus at the Boiling and the Critical Points.

Having studied the volumes of carbon and hydrogen in the side chains, it is now necessary to examine the nuclei more particularly. It is natural to suppose that the apparent volumes of carbon and bydrogen still stand in the relation of 4 to 1 in the nucleus, although their absolute values might differ from those in the paraffins under similar circumstances. The following table gives the value of $\mathrm{V} / \mathrm{W}$ for a number of single ring compounds, none of the hydrogens being displaced by substituents. Thus the relation $\mathrm{C}=4 \mathrm{H}$ is assumed. Nitrogen in pyridine and piperidine is considered to possess the volume $3 \mathrm{~S}$ in accordance with its fundamental valency number, that is to say, it is equal to $3 \mathrm{H}$.

\section{TABLE XVIII.}

Table showing the values of $\mathrm{V} / \mathrm{W}$ for a number of simple cyclic arrangements.

\begin{tabular}{|c|c|c|c|c|c|c|c|}
\hline \multicolumn{2}{|c|}{ Compound. } & $\mathrm{V}_{\text {B.P. }}$ & $w$. & $\mathrm{v} / \mathrm{w}$ & $\mathbf{v}_{\mathrm{K}}$ & w: & $\mathrm{V} / \mathrm{W}$. \\
\hline Benzene, & $\mathrm{C}_{6} \mathrm{H}_{6} \ldots$ & 96 & 30 & $3 \cdot 20$ & 2563 & 30 & $8 \cdot 54$ \\
\hline Hexahydrobenzene, & $\mathrm{O}_{6} \mathrm{H}_{12} \ldots \ldots$ & $116 \cdot 3$ & 36 & $3 \cdot 23$ & $306 \cdot T$ & 36 & $8 \cdot 5 \cdot 2$ \\
\hline Pyridine, & $\mathrm{C}_{\overline{\hat{n}}} \mathbf{H}_{\overline{\hat{j}}} \mathbf{N} \ldots$ & $89 \cdot 3$ & 28 & $3 \cdot 19$ & $\Delta=49 \cdot 6$ & for & $\mathrm{H}_{6}$. \\
\hline Piperidine, & $\mathrm{C}_{\vec{n}} \mathrm{H}_{11} \mathrm{~N} \ldots$ & $108 \cdot 8$ & 34 & $3 \cdot 20$ & H & $=$ & $8 \cdot 3$. \\
\hline Paraffins & & $\ldots$ & $\ldots$ & 3.70 & $\ldots$ & $\ldots$ & $9 \cdot 66$ \\
\hline
\end{tabular}

The above table shows very clearly that the relation between the volumes of carbon and hydrogen is the same in the nucleus as in the side chains, and as in the paraffins. 
Incidentally, nitrogen is shown to possess the volume $3 \mathrm{~S}$, so that $\mathrm{H}: \mathrm{C}: \mathrm{N}=1: 4: 3$.

A remarkable result of the above calculations is that no allowance for the so-called double bonds is to be made in benzene and its homologues. This is especially noticed in an extended study of benzene and hexamethylene to be made later (see Table XXII.).

The absolute apparent volumes of carbon and hydrogen in the compounds included in the table are considerably smaller than those found in aliphatic hydrocarbon chains under similar circumstances. It is clearly inadmissible to compare their volumes, and to work out volume relations, without first taking into account their different constitutions : this may be done by allowing a definite contraction for ring-structure.

Conclusion.-The relative volumes of $\mathrm{C}$ and $\mathrm{H}$ are still as $4: 1$ in the nuclei, but their absolute values differ from those in the side chains or in the paraffin hydrocarbons.

(iv.) The Amount of the Contraction in Aromatic Compounds for Ring-structure at the Boiling-Point.

Because benzene and its derivatives have almost the same volumes as those of certain homologous paraffin hydrocarbons, Kopp supposed that the apparent atomic volumes of $\mathrm{C}$ and $\mathrm{H}$ at the boiling-point are 11 and 5.5 respectively. This conclusion no doubt was arrived at because of a similarity in the volumes of certain paraffin hydrocarbons and a series - of homologous benzene derivatives. The above compounds are shown in the following table.

\section{TABLE XIX.}

Table of comparison of the Volumes of Aromatic and Paraffin Hydrocarbons at the B.P.

\begin{tabular}{|c|c|c|c|c|c|}
\hline \multicolumn{2}{|c|}{ Aromatic Compounds. } & \multirow{2}{*}{$\frac{V .}{96}$} & \multicolumn{2}{|c|}{ Paraffins. } & V. \\
\hline Benzene, & $\mathrm{C}_{6} \mathrm{H}_{6} \ldots \ldots \ldots$ & & Butane, & $\mathrm{C}_{4} \mathrm{H}_{10}$. & 959 \\
\hline Toluene, & $\mathrm{C}_{7} \mathrm{H}_{8}$. & $118 \cdot 3$ & Penfane, & $\mathrm{C}_{5} \mathrm{H}_{12}$ & $117 \cdot 8$ \\
\hline m-Xylene, & $\mathrm{C}_{8} \mathrm{H}_{10}$ & $140 \cdot 0$ & Hexane, & $\mathrm{C}_{6} \mathrm{H}_{14} \cdot$ & 139.93 \\
\hline Mesitylene, & $\mathrm{C}_{9} \mathrm{H}_{12} \quad \cdots$ & $162 \cdot 8$ & Heptane, & $\mathrm{C}_{\gamma} \mathrm{H}_{1} \ldots \ldots \ldots$ & $162 \cdot 66$ \\
\hline Cymene, & $\mathrm{C}_{10} \mathrm{H}_{14} \ldots \ldots$ & $184 \cdot 5$ & $\begin{array}{l}\text { Octane, } \\
\text { sec. Octane }\end{array}$ & $\begin{array}{l}\mathrm{C}_{8} \mathrm{H}_{16} \ldots \ldots \ldots \\
\mathrm{C}_{b} \mathrm{H}_{16}, \ldots \ldots \ldots\end{array}$ & $\begin{array}{l}186 \cdot 26 \\
184\end{array}$ \\
\hline
\end{tabular}

Phil. May. S. 6. Vol. 16. No. 91. July 1908. 
Kopp's reasoning was somewhat as follows:-

M.V. of Benzene, $\mathrm{C}_{8} \mathrm{H}_{6} \ldots \ldots \ldots \ldots . . .66$

M.V. of Butane, $\mathrm{C}_{4} \mathrm{H}_{10} \ldots \ldots \ldots \ldots \ldots . . \ldots 6^{\circ}$

Thus 2 vols. of $\mathrm{C}=4$ vols. of $\mathrm{H}$, and $\mathrm{C}=2 \mathrm{H}$.

But 1 vol. of $\mathrm{CH}_{2}=22$.

Therefore

1 vol. of $\mathrm{C}=\frac{22}{2}=11$, and 1 vol. of $\mathrm{H}=\frac{11}{2}=5 \cdot 5$.

The similarities found in the above table, however, are illusive, for the two series are not comparable; that is to say, the apparent volumes of the atoms in the nucleus of aromatic compounds are not the same in size as those in the paraffin hydrocarbons. The well-known difference in their constitutions is marked by a very important difference in their volumes, a constitutive effect which is of the nature of a contraction.

The complex $\mathrm{C}_{6} \mathrm{H}_{6}$ in the paraffin hydrocarbon series possesses a volume of $30 \times 3 \cdot 7=111$ at the boiling-point, so that on passing from the aliphatic to the aromatic series a contraction of $111-96=15$ occurs. This is characteristic of all compounds possessing the hexacyclic ring.

Vol. of complex, $\mathrm{C}_{6} \mathrm{H}_{6} \quad \ldots \ldots \ldots .96+15=111$.

Vol. of butane, $\mathrm{C}_{4} \mathrm{H}_{10} \quad \ldots \ldots \ldots .96$.

Therefore 2 vols. of $\mathrm{C}=4$ vols. of $\mathrm{H}+15=8$ vols. of $\mathrm{H}$, and 1 vol. of $\mathrm{C}=4$ vols. of $\mathrm{H}=4 \mathrm{~S}$.

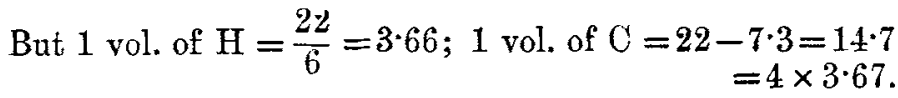

It must be remarked that the similarity between the amount of the contraction and an integral number of unit-steres of hydrogen volumes is quite a coincidence and does not hold under other conditions.

Direct evidence for the above contraction is found in the following :-

$$
\begin{aligned}
& \text { M.V. of Heptylene, } \quad \mathrm{O}_{\mathbf{\tau}} \mathrm{H}_{14} \ldots \ldots \ldots \ldots \ldots \ldots \text { 154:8 } \\
& \text { M.V. of } 6 \text { Hydrotoluene, } \mathrm{C}_{7} \mathrm{H}_{14} \ldots \ldots \ldots \ldots \ldots . .142 \cdot 3 \\
& \text { M.V. of Octylene, } \quad \mathrm{C}_{8} \mathrm{H}_{16} \ldots \ldots \ldots \ldots \ldots \ldots . . .17766 \\
& \text { M.V. of } 6 \text { Hydroxylene, } \mathrm{C}_{8} \mathrm{H}_{16} \ldots \ldots \ldots \ldots \ldots . .164 \cdot 3
\end{aligned}
$$

$13 \cdot 3$

The above comparisons have already been made by Horstmann (Ber. 1890, xx. p. 766). The following further evidence may be adduced :-

M.V. of Benzene, $\mathrm{C}_{6} \mathrm{H}_{6}+6 \mathrm{H}=\left(\mathrm{C}_{6} \mathrm{H}_{12}\right)=96+22 \cdot 2=118 \cdot 2$

M.V. of Hexylene, $\mathrm{C}_{6} \mathrm{H}_{12}$

M.V. of $p$ Xylene, $\mathrm{C}_{8} \mathrm{H}_{10}+6 \mathrm{H}=\left(\mathrm{C}_{7} \mathrm{H}_{14}\right)=1405+22 \cdot 2=162 \cdot 7$

M.V. of Octylene, $\mathbf{C}_{7} \mathbf{H}_{14}$ $177 \cdot 6$ 
TABLE XX.

The following gives the values of the Contractions for a number of Hexacyclic Compounds.

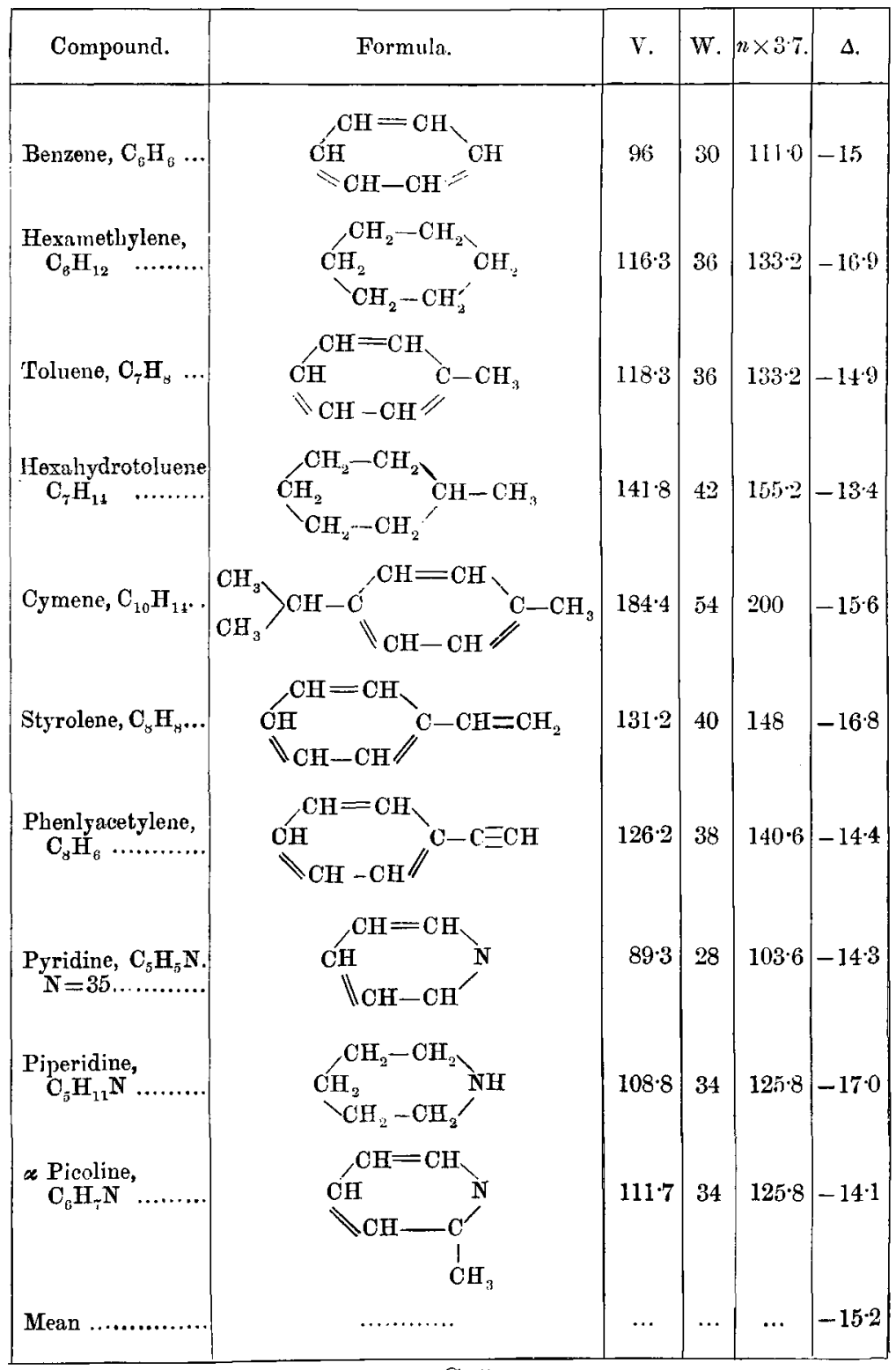


It is seen from the above table that a contraction of about 15 is observable in compounds possessing a hexacyclic ring. Paraldehyde $\mathrm{C}_{6} \mathrm{H}_{12} \mathrm{O}_{3}$, which is a fatty derivative, with a cyclic structure, also manifests a similar contraction (15.8). Certain other compounds, such as thiophene, pyrrol, furfurla, also possess a very marked contraction, that is one of about 11 units. This smaller value is due to the fact that the complexity of these rings is less than those given in the above table. A consideration of the above compounds is reserved for the present.

Diamylene $\mathrm{C}_{10} \mathrm{H}_{20}$ may, however, be mentioned here.

Formula :<smiles>CC(C)C1CC(C(C)C)C1</smiles>

V. $211 \cdot 3$, W. $60, n \times 3 \cdot 7222 \cdot 0$, contraction - $10 \cdot 7$.

This case of diamylene, as well as that of paraldehyde, is a striking verification of the idea that there is always a contraction when a compound possesses cyclic structure.

It is now necessary to consider rings of higher complexity than that of benzene for instance (Table XXI. p. 85).

The last compound is referred to in Trans. Chemical Society, 1906, cxi.p. 312. Camphor, which is also considered, nay be shown to be subjest to a contraction of 30.9 ; but since it is only intended to deal in this paper with those compounds which follow the law of valency, as it is generally understood, a number of ring compounds for which data referred to the boiling-point exist cannot be now considered.

The results brought out by Table XXI. show unmistakably that not only is there a special contraction when a compound possesses ring-structure, but that also the amount of the contraction is a function of the complexity of the ring. The above compounds which are distinguished by similar ring structure are the subjects of similir contractions. The average value of the contraction is shown to be $-30^{\circ} 6$. It is remarkable that borneol, and of course camphor, substances which have only recently been shown to possess bridged rings, should manifest contractions similar to those of naphthalene or quinolene, which are bicyclic. Camphene would no doubt manifest a similar contraction. 
TABLE XXI.

Table showing the Contraction for Double Rings.

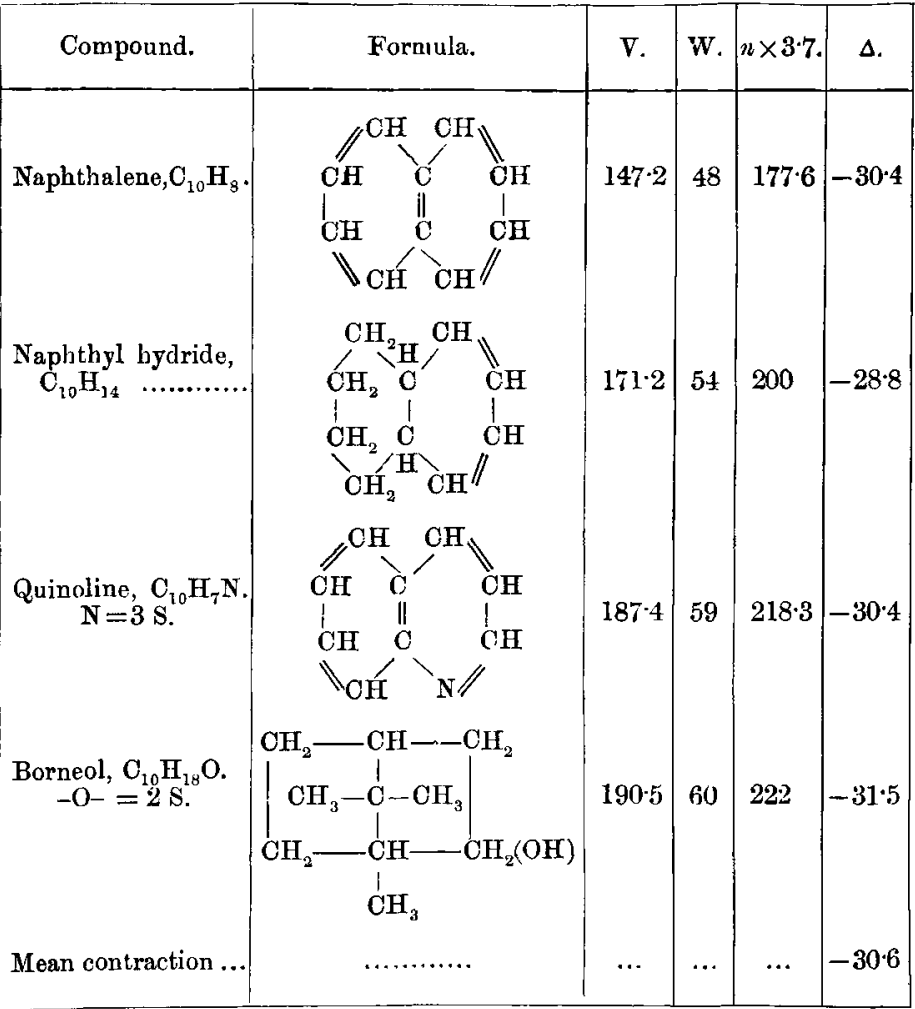

A determination of the molecular volume of a compound at the boiling-point enables us not only to show that it is cyclic, but also, to some extent, the nature of the ring independently of whether it is aliphatic or aromatic.

If the case of carvene $\mathrm{C}_{10} \mathrm{H}_{16}$ be considered, it will be found to be subject to a contraction similar to that characteristic of benzene compounds, and thas the ring is shown not double.

M.V. of carvene $\mathrm{C}_{10} \mathrm{H}_{16}$ at the B.P. is $190.3 ; \mathrm{W}=56$.

Volume of the complex $\mathrm{C}_{10} \mathrm{H}_{16}$ in the fatty series is

$$
=58 \times 3 \cdot 7=207 \cdot 2 \text {; contraction }-16.9 \text {. }
$$

The following table includes two isomeric ring-compounds of high complexity, namely anthracene and phenanthrene. 
They will be shown to manifest still greater contractions than those which have been associated with the cyclic compounds previously considered. This the following table shows.

\section{Table XXII.}

Table giving the Contractions associated with Anthracene and Phenanthrene.

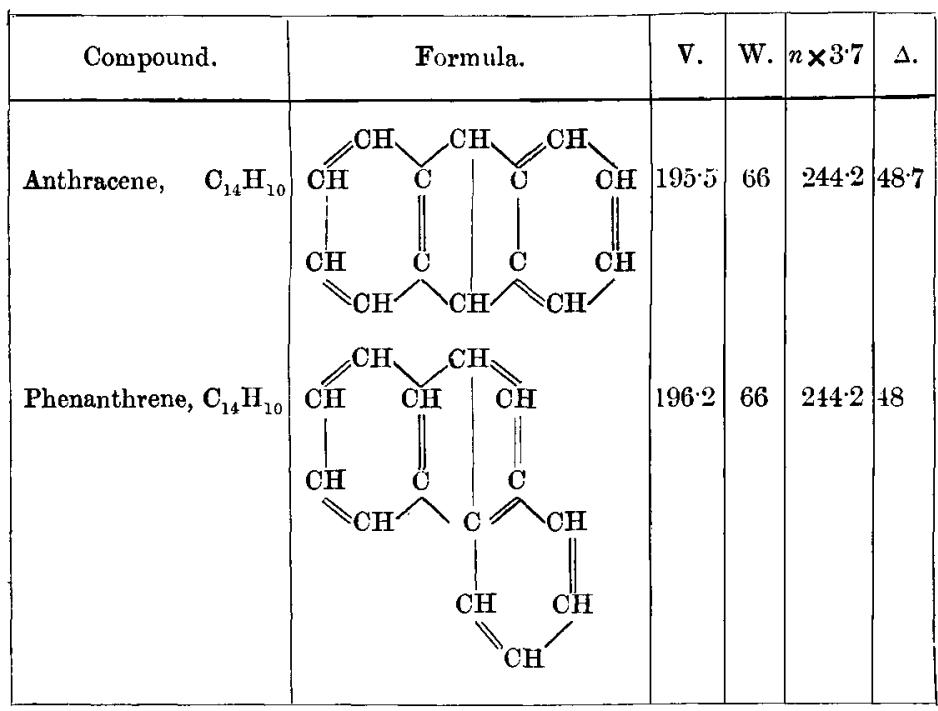

The contractions brought out by the above calculations are quite considerable. No doubt chrysene $\mathrm{C}_{18} \mathrm{H}_{12}$ would manifest a still higher contraction.

The above investigations show that when compounds possess what is usually considered to be cyclic structure a notable contraction occurs. The contractions have magnitudes which are probably dependent on the number of atoms in the nuclei, and on the kind of nuclens. It is scarcely to be doubted that significant additive relations are also to be noticed under all corresponding conditions. Only the barest outline of the theory can here be given, but it is hoped to amplify it as other compounds come up for consideration. A point of practical utility is likely to be found in the possibility of identifying cyclic or nuclear structure in aliphatic compounds, a matter for which there is very litlle physical evidence at present at command. A paper on this subject is in preparation. 
The Volume Relations of Benzene and Hexametlylene under corresponding conditions.

It will be found that a similar thorough treatment is possible for benzene and hexamethylene as was the case with the paraffin hydrocarbons. The references are Young, Trans. Chem. Soc. 1889.

(a) At identically reduced Pressures.

\section{TABLE XXIII.}

Relation between the Values of $\mathrm{V} / \mathrm{W}$ and also of $\mathrm{V} / \mathrm{V}_{\mathrm{K}}$ for $\mathrm{O}_{6} \mathrm{H}_{6}$ and $\mathrm{C}_{6} \mathrm{H}_{12}$ under corresponding conditions.

\begin{tabular}{|c|c|c|c|c|c|c|c|c|}
\hline \multicolumn{5}{|c|}{$\mathrm{C}_{6} \mathrm{H}_{12}, \mathrm{~W}=36$} & \multicolumn{4}{|c|}{$\mathrm{C}_{\mathrm{v}} \mathrm{H}_{i j}, \mathrm{~W}=30}$. \\
\hline$P / P_{K}$ & $T / T_{K}$ & V. & $\mathbf{v} / \mathbf{W}$ & $\mathrm{V} / \mathrm{V}_{\mathrm{K}}$ & $\mathrm{T} / \mathrm{T}_{\mathrm{K}}$ & V. & $\mathrm{V} / \mathrm{W}$. & $V / V_{K}$. \\
\hline 001474 & .5096 & 1063 & 2.95 & .3466 & .5098 & $87 \cdot 86$ & $2 \cdot 93$ & 3424 \\
\hline .002949 & .5354 & $108 \cdot 74$ & $3 \cdot 00$ & $35 \div 6$ & .5359 & $89 \cdot 45$ & 298 & $\because 489$ \\
\hline$\cdot 005898$ & $\cdot 5646$ & $110 \cdot 32$ & 3.06 & 3597 & $\cdot 56+8$ & $91 \cdot 24$ & 304 & 3560 \\
\hline .011797 & .5985 & $112 \cdot 97$ & $3 \cdot 14$ & $\cdot 3684$ & $\cdot 5989$ & 9350 & $3 \cdot 12$ & $36+8$ \\
\hline$\cdot 022411$ & $\cdot(6330)$ & $115 \cdot 85$ & $3 \cdot 20$ & 3777 & $633 t$ & $95 \cdot 91$ & $3 \cdot 2 \cdot 2$ & $\because 3742$ \\
\hline .044232 & 6759 & 119.82 & 3.33 & 3907 & $67(65)$ & $99 \cdot 19$ & 330 & .3870 \\
\hline .088465 & $727 \bar{t}$ & $125 \cdot 37$ & $3 \cdot 48$ & 4088 & 7282 & 10360 & $3 \cdot 45$ & $\cdot 4053$ \\
\hline$\cdot 14744$ & .7714 & $130 \cdot 89$ & 3.64 & -4263 & .7725 & $1(18 \cdot 49$ & 301 & $\cdot 1233$ \\
\hline .20642 & .8041 & $135 \cdot 68$ & 3.77 & $\therefore 424$ & .8052 & 11249 & 375 & $\cdot 4389$ \\
\hline 29488 & .8428 & $142 \cdot 54$ & 3.96 & $46+8$ & 8499 & 117.95 & 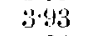 & $\cdot 4602$ \\
\hline$\cdot 44232$ & $\cdot 8901$ & $153 \cdot 27$ & $4 \cdot 26$ & -4997 & -8906 & $1 \div 7 \cdot 12$ & 4.24 & $\cdot 4960$ \\
\hline .58978 & .9267 & $165 \cdot 17$ & 4.59 & 5385 & .9270 & $137 \cdot 2$ & $45 \pi$ & -5353 \\
\hline$\cdot 73721$ & $\cdot 9566$ & $180 \cdot 13$ & 500 & 5873 & 9366 & $1 \pm 9 \cdot 8$ & 498 & .5845 \\
\hline .82568 & 9720 & 191.74 & $5: 32$ & 6252 & .9725 & $160 \cdot 19$ & 534 & (i.250 \\
\hline $.9+363$ & .9914 & $220 \cdot 87$ & $6 \cdot 13$ & .7201 & .9915 & $18 \div-3$ & 6.07 & 7113 \\
\hline 97313 & $\cdot 9960$ & 235.96 & 6.55 & $\cdot 7693$ & & & & \\
\hline 1.00000 & 1.0000 & 3067 & 8.52 & 1.0000 & 10000 & 2563 & $8 \cdot 54$ & $1 \cdot 0000$ \\
\hline
\end{tabular}

The above table is very instructive. It shows in the first place that the rolumes of benzene and hexamethylene are very nearly in the ratio $30: 36$ under conditions of corresponding pressure. This ratio is similar to that between the valency numbers. It is thus seen that the ratio of the volumes of carbon and hydrogen is still as $4: 1$, although the series is quite different to that of the parafin hydrocarbons. Such a regularity is most remarkable, and the probability is very great that the additive relations found to exist under corresponding conditions will ultimately be found to be connected with a kind of liquid structure which has been little suspected. 
The volume relations of the atoms in benzene and hexamethylene at the critical point may also be investigated in a direct way.

$$
\begin{aligned}
& \text { M.V. of } \mathrm{C}_{6} \mathrm{H}_{12} \text {. . . . . } 306 \cdot 7 \\
& \text { M.V. of } \mathrm{C}_{6} \mathrm{H}_{6} \text {. . . . . } 256 \cdot 3 \\
& \text { Volume of } 6 \mathrm{H} \quad \overline{50 \cdot 4}
\end{aligned}
$$

Therefore $\mathrm{H}$ has a volume of $8 \cdot 4$.

The volume of

The volume of

$$
\begin{aligned}
& 6 \mathrm{C}=\text { vol. of } \mathrm{C}_{6} \mathrm{H}_{6}-\text { vol. of } \mathrm{H}_{6}=256 \cdot 3-50 \cdot 4 \\
& =205 \cdot 9
\end{aligned}
$$

$$
\begin{aligned}
& 6 \mathrm{C}=\text { vol. of } \mathrm{C}_{6} \mathrm{H}_{12} \text {-vol. of } \mathrm{H}_{12}=306 \cdot 7-100 \cdot 8 \\
& =205 \cdot 9
\end{aligned}
$$

The volume of $\mathrm{C}$ is thus $=\frac{205 \cdot 9}{6}=34 \cdot 3=4 \times 8 \cdot 57$.

It is thus conclusively shown that the volumes of benzene and hexamethylene are proportional to their valency numbers at the critical point, and that the volumes of carbon and hydrogen are respectively as 4 to 1 , which is the same as the relation existing between their valency numbers. This has be on shown to be approximately true at all corresponding pressures.

One other point connected with the above table deserves attention. It has been shown that the homologues of benzene as well as benzene itself possess volumes at the boiling-point which are the same, or nearly the same, as those of certain hydrocarbons of the paraffin series. Thus benzene $\mathrm{C}_{6} \mathrm{H}_{6}$ has a volume at the boiling point, which is the same as that of butane $\mathrm{C}_{4} \mathrm{H}_{10}(96)$, and this is also approximately true at the critical point. $V_{\mathrm{K}}$ for benzene $256^{\circ} 3 ; \mathrm{V}_{\mathrm{K}}$ for butane 251 approx. The volume of toluene $\mathrm{C}_{7} \mathrm{H}_{8}$ at the boiling-point is also similar to that of pentane $\mathrm{C}_{4} \mathrm{H}_{12}$. Hexamethylene $\mathrm{C}_{6} \mathrm{H}_{6}$ has a volume $\left(116^{\circ} 3\right)$ not very different from that of pentane 117.8. It is found that if the volumes of pentane and hexamethylene be compared under conditions of corresponding pressures from the critical vapour-pressure downwards, the parallelism between the two series of molecular volumes is maintained. No doubt the molecular volumes of butane and benzene under similar conditions are the same or nearly so. These results are of course due to the validity of the law of corresponding states.

It may not be without interest to show in one table that the law of corresponding states and the law of additivity are approximately true for $\mathrm{C}_{6} \mathrm{H}_{6}$ and $\mathrm{C}_{6} \mathrm{H}_{12}$. 
Table XXIV.

Table showing the validity of the Law of Corresponding

States and of Additivity for $\mathrm{C}_{6} \mathrm{H}_{6}$ and $\mathrm{C}_{6} \mathrm{H}_{12}$.

\begin{tabular}{|c|c|c|c|c|c|}
\hline \multicolumn{3}{|c|}{$\mathrm{C}_{6} \mathbf{H}_{6}$} & \multicolumn{3}{|c|}{$\mathbf{C}_{\mathrm{t}} \mathbf{H}_{12}$} \\
\hline $\mathrm{P} / \mathrm{P}_{\mathrm{K}}$ & V. & $\mathrm{V} / \mathrm{v}_{\mathrm{K}}$. & $\nabla^{\prime}$ & $V^{\prime} / \nabla^{\prime}{ }^{\prime}$ & $\nabla^{\prime} / \mathrm{V}$. \\
\hline $\begin{array}{c}\cdot 001474 \\
.005898 \\
.022411 \\
.088465 \\
.20642 \\
.44232 \\
.737: 21 \\
.94363 \\
1.00000\end{array}$ & $\begin{array}{r}87 \cdot 86 \\
91 \cdot 24 \\
95 \cdot 91 \\
103 \cdot 60 \\
112 \cdot 49 \\
127 \cdot 12 \\
149 \cdot 8 \\
182 \cdot 3 \\
256 \cdot 3\end{array}$ & $\begin{array}{r}\cdot 3432 \\
-3560 \\
\cdot 3742 \\
\cdot 4042 \\
\cdot 4385 \\
\cdot 4960 \\
\cdot 5845 \\
\cdot 7112 \\
1 \cdot 0000\end{array}$ & $\begin{array}{l}106 \cdot 3 \\
110 \cdot 32 \\
115 \cdot 85 \\
125 \cdot 37 \\
135 \cdot 68 \\
153 \cdot 27 \\
180 \cdot 13 \\
220 \cdot 87 \\
306 \cdot 7\end{array}$ & $\begin{array}{r}\cdot 3466 \\
-3597 \\
.3777 \\
\cdot 4084 \\
\cdot 4423 \\
.4997 \\
.5873 \\
.7202 \\
1 \cdot 0000\end{array}$ & $\begin{array}{l}1 \cdot 209 \\
1 \cdot 208 \\
1 \cdot 208 \\
1 \cdot 210 \\
1 \cdot 206 \\
1 \cdot 206 \\
1 \cdot 202 \\
1 \cdot 211 \\
1 \cdot 197\end{array}$ \\
\hline \multicolumn{5}{|c|}{$\begin{array}{l}\text { Mean } \\
\text { Theoret }\end{array}$} & $\begin{array}{l}1 \cdot 206 \\
1 \cdot 200\end{array}$ \\
\hline
\end{tabular}

The above results show in the first place that the ratio $\mathrm{V} / \mathrm{V}_{\mathrm{K}}$ for $\mathrm{C}_{6} \mathrm{H}_{12}$ is somewhat larger than that for $\mathrm{C}_{6} \mathrm{H}_{6}$. This is also true of the ratios $V / W$.

Secondly, the ratio $\mathrm{V}^{\prime} / \mathrm{V}$, which gives the volume of hexamethylene relative to benzene, is very nearly equal to the quotient of their respective valency numbers.

Table XXV. gives the volumes of the compounds under conditions of corresponding pressure, but owing to the fact that the values $\mathrm{T} / \mathrm{T}_{\mathrm{K}}$ are nearly the same in the two cases, a special investigation of the volume relations of benzene and hexamethylene at corresponding temperatures is unnecessary.

\section{TAble XXV.}

The relation of $\mathrm{W}$ to the Critical Coefficients of Aromatic Compounds.

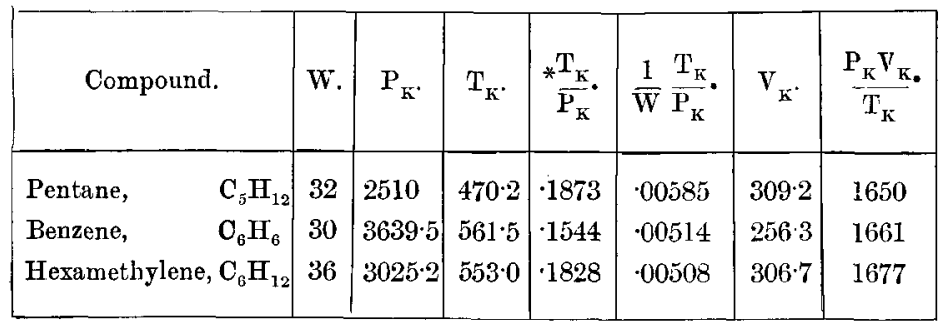

* $T_{K}$ is expressed in degrees centigrade, $P_{K}$ in cms. of mercury. 
While the values of $\frac{1}{W} \frac{T_{K}}{P_{K}}$ are very similar for the two compounds $\mathrm{C}_{6} \mathrm{H}_{6}$ and $\mathrm{C}_{6} \mathrm{H}_{12}$, they are quite different from the value attacbing to $\mathrm{C}_{5} \mathrm{H}_{12}$. The difference amounts to about 15 per cent. of the whole. This indicates a large constitutive effect which has already been traced to ringstructure.

In order to show the great probability of similar additive relations being observable at the critical point as at the boiling point in the case of the homologues of benzene, a table is given of critical coefficients quoted by Guye (Bull. de la Soc. Chim. (3) xiii. p. 34). These are shown to be subject to a nearly constant diminution in $\frac{\mathrm{T}_{\mathrm{K}}}{\mathrm{P}_{\mathrm{K}}}$. The critical temperatures are absolute and the pressures are expressed in atmospheres.

\section{TABLe XXVI.}

Table of Critical Coefficients.

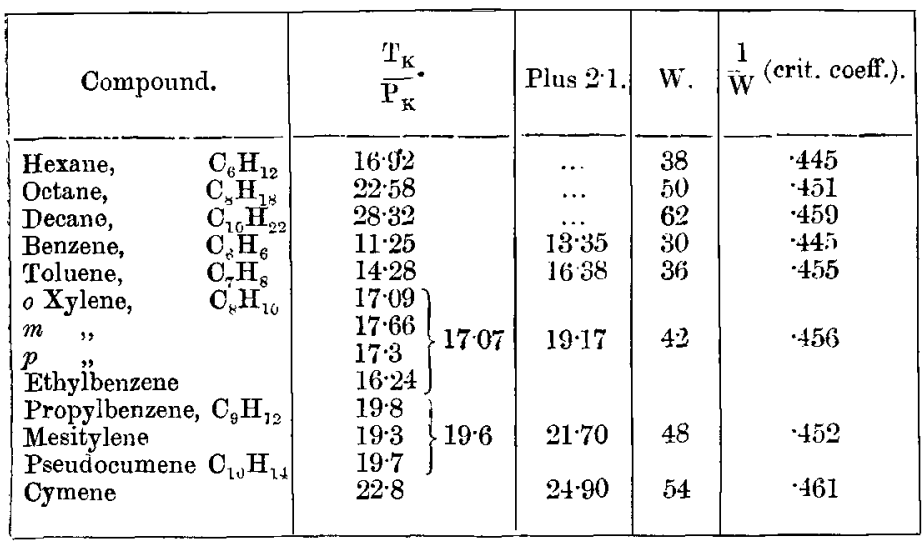

When the number attaching to benzene and its homologues is augmented by $2 \cdot 10$ and the sum divided by the valency numbers, the quotients are found to be about equal to those obtained by dividing the critical coefficients of the paraffin hydrocarbons by their respective valency numbers. It must therefore be concluded that $2 \cdot 1$ represents the change in $\frac{T_{K}}{P_{K}}$ which occurs on passing from the paraffins to the aromatic compounds. Since $\mathrm{V}_{\mathrm{K}}=\frac{\mathrm{T}_{\mathrm{K}}}{\mathrm{P}_{\mathrm{K}}} \times$ constant, the molecular 
eritical volumes are proportional to the critical coefficients and are thus subject to similar additive relations. It is, however, highly probable that these would be still more clearly shown in the molecular critical volumes. The volumes of the sidechains in the benzene homologues are thus equal to corresponding paraffinoid residues, while the nucleus undergoes a contraction.

$\begin{aligned} & \text { M.V. of } \mathrm{C}_{6} \mathrm{H}_{12} \text { at B.P. } 116 \cdot 3 \text {. M. } \mathrm{V}_{\mathrm{k}} \text {. of } \mathrm{C}_{6} \mathrm{H}_{12}= 306 \cdot 7 \text {. } \\ & \text { Ratio } 2 \cdot 64 \text {. }\end{aligned}$ M.V. of $\mathrm{C}_{7} \mathrm{H}_{10}$ (Toluene) at B.P. 118.3. Calculated M.V $\mathrm{K}_{\mathrm{K}}$. of $\mathrm{C}_{7} \mathrm{H}_{10}=118 \cdot 3 \times 2 \cdot 64=313 \cdot 3$,

Vol. of $\mathrm{CH}_{2}$ at the Critical Point $=$ Vol. of $\mathrm{C}_{7} \mathrm{H}_{8}-$ Vol. of $\mathrm{C}_{6} \mathrm{H}_{6}$ $=313 \cdot 3-256 \cdot 3=57$.

Vol. of $\mathrm{H}$ in side-chain $=\frac{57}{6}=9 \cdot 5$,

which is about equal to that in the paraffin hydrocarbons.

\section{SUMMARY.}

It has been found that at the melting-point and at equal intervals of temperature therefrom the molecular volumes of the olefines may be expressed by the following formula:

$$
\text { M. vol. } \quad \mathrm{C}_{n} \mathrm{H}_{2 n}|=|=6 n \mathrm{~S}-2 \cdot 62=\mathrm{WS}-|=|
$$

the aretylenes by the following:

$$
\text { M. vol. } \mathrm{C}_{n} \mathrm{H}_{2 n-2}|\equiv|=6 n \mathrm{~S}-2 \mathrm{~S}-3=\mathrm{WS}-1=1 \text {; }
$$

the specific gravities of the above compounds are at equal intervals of temperature from the melting-points equal fractions of the specific gravities at those points.

The molecular volume of a single olefine and acetylene is at the boiling-point expressed by the following formulæ:-

$$
\begin{aligned}
& \text { M. vol. of } \mathrm{C}_{n} \mathrm{H}_{2 n}=6 n \mathrm{~S} \text { (Olefines). } \\
& \text { M. vol. of } \mathrm{C}_{n} \mathrm{H}_{2 n-2}=6 n \mathrm{~S}-2 \mathrm{~S} \text { (Acetylenes). }
\end{aligned}
$$

The value of $\mathrm{S}$ is usually about $3 \cdot 7$, but may vary slightly from compound to compound. In so far as 3.7 is const:int the above formulæ are general for a series.

3.7 is the atomic volume of $\mathrm{H}$. The atomic volume of carbon is $\mathbf{1 4} \cdot 8$, which numbers are also those of similar atoms in the paraffins. Thus $\mathrm{C}=4 \mathrm{~S}=4 \frac{\mathrm{V}}{\mathrm{W}}$, the symbols having the same meaning
as before. 


\section{Aromatic Compounds.}

It is found that the possession of ring structure on the part of a compound corresponds with an extra contractionthat is to say, the atomic volumes in ringed molecules are always less than the volumes of similar atoms in straight chain compounds, so that the total molecular volume is on the whole less than that of a similar complex in the fatty series.

The relative volumes of atoms in the nuclei are the same as those in straight chain compounds.

Thus it is found that the volumes of benzene and hexamethylene are proportional to their valency numbers from the critical point downwards, so that $\mathrm{C}=4 \mathrm{H}$ as before.

The volumes of the atoms in aliphatic side chains are, however, the same as in the paraffins.

It has been found that the critical coefficients of benzene and its homologues manifest similar relations to those shown by the molecular volumes.

Note--It should be mentioned that Barlow and Pope take the view that the relative volumes of the atoms in the molecular complexes, aromatic as well as aliphatic, are always maintained and that the volume of an atom in a compound is always proportional to its fundamental valency.

Municipal School of Technology, Victoria University, Manchester.

V. The Decomposition of Water Vapour by Electric Sparks. By Alf red Holt, Jun., and Edwin Hopkinson*.

THE decomposition of a compound gas such as watervapour, or carbon dioxide, by electric sparks, and the separation and arrangement of the resulting products about the electrodes, is of special interest since it may be expected to show how far the hypothesis of electrolysis in liquids is applicable to gases.

Almost half a century ago Perrot (Ann. Chim. et Phys. 1861, p. 161) showed that the decomposition of water-vapour took place along the entire path of the spark and not only in the neighbourhood of the electrodes, and that the gas collected from the anode contained an excess of oxygen, while that from the eathode contained an excess of hydrogen, their amounts being equivalent to the copper deposited in a voltameter placed in the same circuit. His experiments

* Communicated by the Authors. 